\title{
Olivier THÉVENON*
}

\section{Increased Women's Labour Force Participation in Europe: Progress in the Work-Life Balance or Polarization of Behaviours?}

\begin{abstract}
Although the increase in female labour force participation is a fairly widespread trend, there is still a considerable diversity of situations across Europe from north to south. To identify the factors that may explain these differences, Olivier THÉVENON uses data from the European Labour Force Surveys (EU-LFS) carried out in 14 countries between 1992 and 2005. For comparable educational levels and family situations (e.g. number of children, age of youngest child, single-parent status), the labour market behaviours of European women (inactive, short or long part-time work, full-time work) are very diverse. This diversity reflects differences in government policies targeting working mothers (help with reconciling work and childcare, encouragement to leave the labour market or to work part-time, etc.). In some contexts, women choose to postpone childbirth or to remain childless in order to pursue a working career. The increase in women's labour force participation may thus entail a certain polarization of behaviours.
\end{abstract}

The development of female labour market participation in most European countries dates back to the 1970s. At the outset it was viewed negatively as a potential factor of increased unemployment and as one of the main causes of the simultaneous fertility decline observed at that time. However, the image of working women improved in the 1980s and especially in the 1990s. There are several reasons for this, including the beneficial effects of productivity gains and the economic growth generated by the employment of a relatively qualified workforce. Higher female employment helps to rebalance the economic dependency ratio, and is good for the long-term financing of social security systems faced with the costs of an ageing population. It can also be a response

\footnotetext{
* Institut national d'études démographiques (INED), Paris.

Correspondence: Olivier Thévenon, INED, 133 boulevard Davout, 75980 Paris Cedex 20, e-mail: olivier.thevenon@ined.fr
} 
to the problem of growing family poverty. Last, the emergence of a positive correlation between fertility rates and the female employment rate in OECD countries from the end of the 1990s (which had been negative until the mid1980s) gave credence to the idea that women's labour force participation could increase without lowering fertility levels (Ahn and Mira, 2002; D'Addio-Dervaux and Mira d'Ercole, 2005).

Despite this more favourable climate, several issues remain unresolved. The first concerns the nature of the change reflected in the switch from a negative to positive association between fertility rates and female labour participation. For Engelhardt et al. (2004) and Kögel (2004), the positive correlation observed at country level does not imply that the relationship between "demand for children" and "supply of labour" at micro-individual level is necessarily positive. On the contrary, it remains negative because women with fewer children are more likely to work in all countries. But that observation is not incompatible with the fact that the highest female employment rates are found in the countries that also have the highest fertility rates. At the same time, the incompatibility between fertility and female labour participation has decreased in most OECD countries, in part as a result of government policies to help parents reconcile their work and family lives (Ahn and Mira, 2002; OECD, 2007).

The second issue concerns the development of part-time work and its contribution to the growth of female employment. In fact, its role is ambiguous since it coincides with the process of developing labour market "flexibility" and reconciling the work-life balance. Part-time work provides access to employment for categories of women who would not otherwise have been able to work. But it can also serve to marginalize women since the jobs are often concentrated in so-called "secondary" market sectors, with low wages, poor working conditions and limited career prospects (Blossfeld and Hakim, 1997). Furthermore, wages from part-time work are not always sufficient to move out of poverty or provide women with real economic independence, and do not guarantee the "emancipation" that work is supposed to provide.

Since the early 1990s, a vast corpus of comparative literature has been devoted to understanding inter-country differences in women's labour market behaviour. These analyses identify different "regimes" of female activity corresponding to behaviour patterns linked to their family situations, and in which part-time work has a variable role. These differences are anchored in a diversity of modes of regulation governing the link between public policies and family solidarity, gender relations and labour market organization. However, the groups of countries identified in terms of the work-family relationship only partly coincide with the broader typology of welfare state regimes proposed by G. Esping-Andersen in the early 1990s (Esping-Andersen G., 1990; Gornick et al., 1997; Thévenon, 2006; Meulders and O'Dorchai, 2007). This typology does not reflect the full range of different labour market behaviours, and the 
trends observed are relatively contrasting, depending on the scope of the worklife balance policies deployed in each country (OECD, 2007).

In this context, the aim of this paper is to analyse the disparities in women's labour force participation in Europe by taking into account their family situation and the role of part-time work, differentiated according to its weekly duration. We will examine how the presence of a child or children affected women's employment from the early 1990s to the mid 2000s. Considerable differences are found in the relationship between employment and family situation in the continental European, Mediterranean and Eastern European countries. In some cases, the rise in female employment rates may reflect a context more favourable to the work-life balance. Conversely, it may also be associated with a growing polarization of labour market behaviour depending on the presence or absence of children.

For the purposes of our analysis we have used the European Labour Force Surveys (EU-LFS) from 1992 to 2005 harmonized by Eurostat (Eurostat, 2008). The first part presents descriptive statistics on trends in female employment rates and household composition. The impact of household composition on women's labour market participation and its change over time are identified by a log-linear model (see Appendix), whose principles and results are described in the following two sections. Part four presents a summary of the results and interprets them in the light of the institutional contexts and the changes observed over the study period.

\section{Growth in women's employment}

\section{Male-female employment disparities are decreasing in all countries}

Between 1992 and 2005 the female employment rate in the economically active age groups rose in most European countries, with the exception of Sweden, Poland and the Czech Republic (Table 1). On average, growth was stronger for women $(+7.7 \%)$ than for men $(+0.4 \%)$, whose employment rate even fell in Germany, Austria, Sweden, Poland and Portugal. Overall, the gap in male/female employment rates narrowed considerably, from 22.8 to 15.5 percentage points for the European Union as a whole (EU-15), and the standard deviation between national employment rates fell from $12.6 \%$ to $8.6 \%$.

Converting employment rates to full-time equivalents (FTE) reveals differences in the extent of part-time working in each country. This fictitious rate measures the employment levels that would be obtained if all working hours were added up to give a total equivalent number of full-time jobs and allows us to estimate changes in employment rates independently of the spread of part-time work. It shows a clear difference between men and women.

The FTE employment rate in most countries hardly changed for men, or even fell (except in Ireland where it rose sharply), whereas for women it rose 
in all countries with the exception of Germany, Austria, Poland and the Czech Republic. This indicates that women's access to employment has risen in greater proportions than would have been induced by the mere redistribution of a constant volume of labour over the period and by the spread of part-time work. This increase was particularly high in Spain and Ireland, showing that women clearly benefited from the labour market expansion in those countries, as did men, albeit to a lesser extent. In France, however, male employment rates and their FTE hardly changed, whereas both rose for women.

Conversely, FTEs fell in Germany and Austria, showing that the fairly weak "gross" increase in employment was due to a redistribution of labour through the development of part-time work. In Poland and the Czech Republic, employment rates and their FTEs fell for both women and men, since part-time working did not form a sufficient buffer against the drop in employment rates caused by economic recession.

The comparison of women's employment rates, whether gross or expressed in FTE, reveals disparities between certain groups of countries that change over time. The Scandinavian countries (Denmark, Sweden and Norway) have the highest gross employment rate for women in both 1992 and 2005, with more than $70 \%$ of women aged 15-64 in employment. The rate for Finnish women is lower but the small difference between the gross employment rate and FTE shows that employment there is massively full-time, as is the case in the other Scandinavian countries. Gross employment rates are also high in the United Kingdom and in the Netherlands, but when viewed in terms of FTE their situation is comparable to other countries of continental Europe (especially Germany). The large gap between these two measures is explained by the sharp increase in part-time work, which concerns three women out of four in the Netherlands (and one-fifth of men) and four out of ten in the United Kingdom and Germany.

The lowest employment rates are found in the southern and eastern European countries where part-time work is still exceptional and concerns less than one-fifth of all jobs. The trends vary, however, with strong growth in gross employment rates in the Mediterranean countries (particularly Spain), even though the 2005 rate was lower than in most continental European countries. Portugal stands out with a far higher female employment rate in both gross and FTE terms. The Eastern European countries also form a fairly mixed group since employment rates for Polish and Hungarian women are comparable to those in the Mediterranean countries, whereas they are higher for women in the Czech Republic, although rates there are now falling due to the economic slowdown.

\section{A parallel trend to that of decreasing family size}

Alongside the increase in female labour participation, Table 2 shows the change in household composition from 1992 to 2005 as recorded by the 


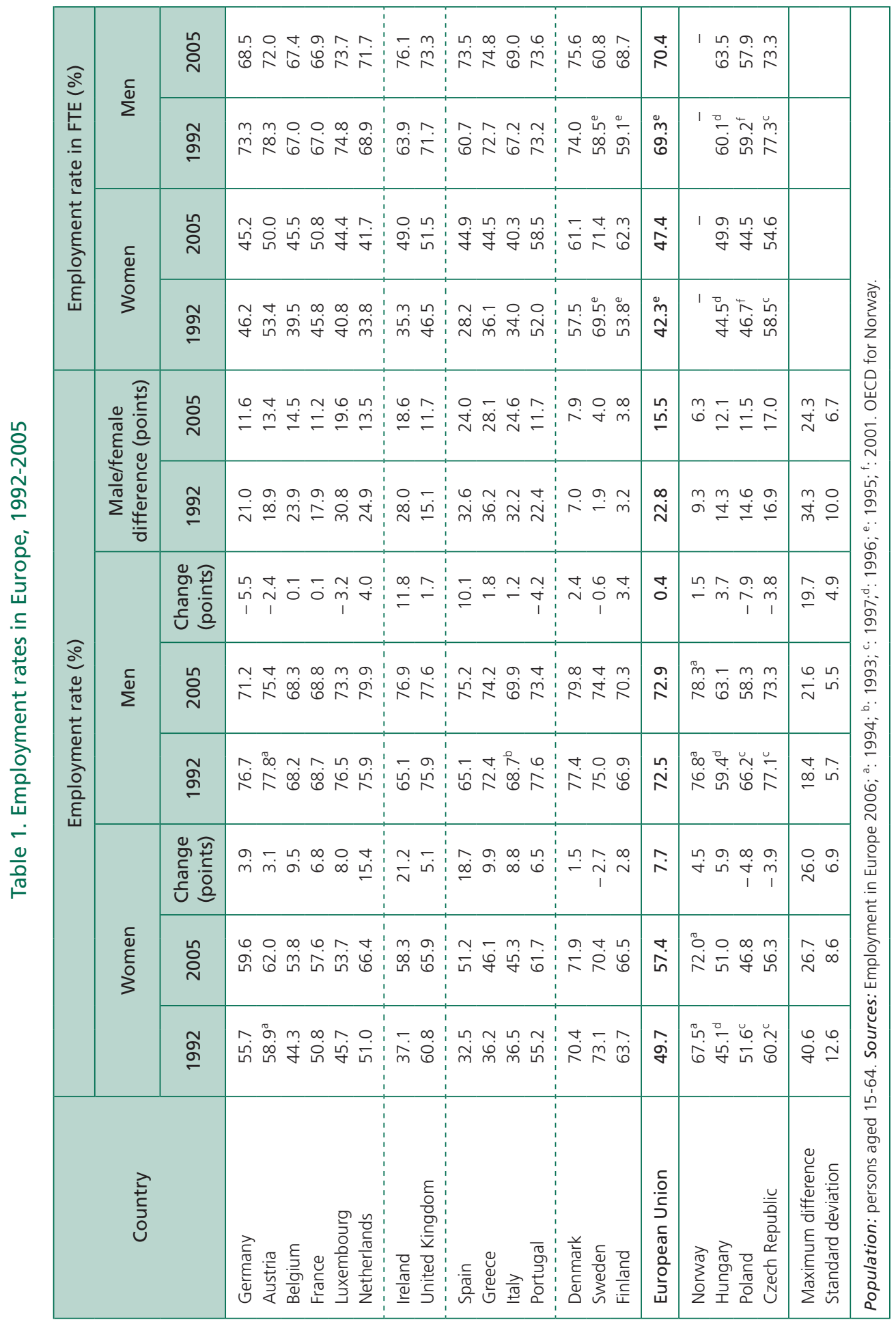


EU-LFS surveys. The proportion of women aged 20-44 living with one or several dependent children ${ }^{(1)}$ is down overall. By contrast, the proportion of women without children has grown in most countries, but to a variable degree. For instance it doubled in Spain and rose sharply in the other southern countries as well as in Germany (where there are considerable differences between Länder). The proportion rose only slightly in Belgium, France, Hungary, the United Kingdom and the Czech Republic, however. The Netherlands and Germany have the highest percentage of childless women whatever the observation date.

The proportions of women with two children or more have declined overall, whereas those of women with one child have remained fairly stable or have even risen slightly. Here again, the southern European countries are marked by a sharper fall in the proportion of women with two children or more.

\section{Modelling female labour force participation and trends}

Several previous studies have examined the relationship between changes in household composition and female labour market behaviour. Among these, Blanchet and Pennec (1993 and 1996) attempted to distinguish the effects of women's stronger attraction to employment for a given family size from the effect of a family size reduction. The authors estimated that from the 1960s to the end of the 1980s, the rise in female employment was due above all to higher labour market participation of women for a given family size, while the degree of competition between employment and the presence of children appears to be fairly constant.

Vlasblom and Schippers (2004) make similar observations for six European countries between 1992 and 1999. Among factors that explain the rise in female employment they distinguished those associated with a change in the characteristics of the female population (including the number and age of their children) from those relating to behavioural changes with given characteristics. They consider that the increase in the women's participation rates is mainly due to changes in labour market behaviour, which nonetheless vary by country.

Our approach differs from preceding ones because we view changes in female labour market behaviour for given family situations. To do so, we model women's employment status according to individual and family characteristics and the year in which these were observed. The aim is to identify the effect of each characteristic as precisely as possible, and for each country, taking into account the multiple interactions that may exist between them. Furthermore the observation period is longer than in previous studies, the number of

(1) Since it is impossible to identify the individual relationship between parent and child, all children in the household are assumed here to be the woman's children. These are therefore all the dependent children in the household, whatever their age. 
countries is larger, and the weekly number of working hours is also taken into account.

\section{Data from EU-LFS Surveys}

The data for the 14 countries were drawn from the annual results of the EU-LFS Surveys. Their main advantage in relation to other potential sources is that they supply standardized information about household composition over a long period, including the educational level and employment status of household members. Since information about educational levels only became available from 1992, we decided to start the study at that date and end it in 2005. However, for Ireland, Luxembourg and the Eastern European countries, data are available for a more limited period.

Information on family composition is partial since relationships to children are only specified for children of the head of household or his spouse, and only if the child is present in the household. ${ }^{(2)}$ To avoid including a large number of women whose children may have left home, we limited our sample to women aged under 45. Since information on household composition is not available in Scandinavian countries, they could not be included in the comparisons below.

Analysis of labour market behaviour is restricted by the lack of information on wage levels and family income. Despite these limitations, we do have detailed information about the employment status of women in relation to their educational level and the composition of the household to which they are attached. The survey years and birthdates of the women enable us to identify age or cohort effects.

The employment situation is observed according to the criterion of labour market participation, with people identified as inactive, job seekers or employed. Employment is differentiated according to its usual weekly duration ${ }^{(3)}$ to account for different types of part-time work. We distinguish between short part-time employment (fewer than 18 hours per week), moderate or long parttime employment (a usual working week of between 19 and 32 hours) and full-time employment (equal to 33 hours per week or more). The European classification includes mothers on maternity leave, but women on parental leave of more than three months are often classified as inactive ${ }^{(4)}$ (Eurostat, 2008).

(2) See Thévenon (2007) for more detail.

(3) Only the working hours of the main job are taken into account here. When the usual working hours are not available we refer to the actual hours worked during the week of the survey.

(4) In principle, all women on paid maternity or parental leave are counted as being in employment. In practice, Eurostat recommendations stipulate that persons on parental leave should be considered in the same way as workers absent from their jobs for other reasons. They should be recorded as "in employment" if their absence is less than three months or if they continue to receive a major share of their wage (more than 50\%). However, the classification of workers on long or unpaid parental leave varies considerably from country to country. In France and Austria they are considered as inactive. 
By compiling available data from 1992 to 2005, we obtain information relative to different pseudo-cohorts of women whose employment situations evolve over the survey years. The age, cohort and period effects, along with the effects of the age of the youngest child are more clearly identified than when the analysis is carried out on a single cross-sectional sample.

\section{A log-linear model of employment situations}

Employment situations are modelled according to the presence of a child or children, the age of the youngest child, when applicable, and the age of the mother at the birth of her first child when two children are identified in the household. Other variables include the presence or not of a spouse differentiated by employment situation and survey year. The women's educational level and year of birth are introduced as control variables, but their impact is not studied here (see Box 1). The log-linear model captures the differences in women's behaviour due to the interaction between the various characteristics. It also distinguishes changes specific to the effect of the presence of children from those due to age and/or cohort effects, and from changes that could be attributed to other characteristics (see the formal presentation in the Appendix).

The model is run separately for each of the 14 countries studied to permit a detailed analysis of the specific interactions that may exist in certain countries. The household composition is considered as an element that precedes the labour supply decision, and to which the labour supply decision adjusts. The model is estimated by minimizing the discrimination information so that information about employment situation variance is shared between the different variables or interactions, making it possible to identify those which contribute most to this variance.

\section{Box 1. Defining the variables}

The variables were introduced into the model by performing certain aggregations that enabled us to maintain sample sizes that were large enough to estimate interactions between variables at several levels.

Data are aggregated into seven two-year groups from 1992 to 2005.

The women included were born between 1944 and 1985 and are counted in three-year age groups. For each year, only women aged 20-44 are counted.

Educational level is presented in three categories based on the ISCED classification: "low" corresponding to primary school education, "intermediate" to secondary education, and "high" to tertiary or above.

The data concerning children is classified using two variables, the number of children divided into five categories $(0,1,2,3+$, unknown), and the age of the youngest child $(0-2$ years, 3- 6 years, 7-11 years, $12-19$ years, $20+$ years).

The age of the mother at the birth of the first child only concerns women with at least two children. We distinguish five categories: 15-19, 20-24, 25-29, 30-34, or 35+.

The spouse is taken into account in terms of his presence or not in the household and his employment status: without spouse, with employed spouse, with unemployed spouse. 


\section{Results of the estimates}

In this section we will present the results corresponding to the estimated effects, all other things being equal, of women's family situations on the estimated frequency of the various employment situations. We will successively analyse the effects of the presence of a child or children, of the age of the youngest child and the timing of the first birth, and of the presence of a spouse (see Appendix for a presentation of the calculation method).

\section{A variable effect of the presence of children and their number on women's labour market activity}

The first set of results concerns the effect of the presence of children on women's labour force participation, all other things being equal. Figure 1 shows the average effect over the period while Figure 2 shows the change over the years of the survey. The effects shown here take into account the average dispersion of labour market situations and the influence of the presence of children on this dispersion. In the second case (Figure 2) we also take account of the interaction with the survey date (see Appendix).

Whatever the country, women are more likely to be inactive if they have a child and this probability increases with the number of children. However, the progressiveness of the effect differs by birth order. In most countries, each child induces a relatively similar effect whatever its birth order, with a few exceptions. In France and in Belgium, the probability of being inactive increases with the birth order and especially with the presence of a third child. A single child has little effect on the probability of being inactive in France. The impact of children is weak in Greece, however, where women without children are much more frequently inactive than in other countries. In the Czech Republic and Hungary it is clearly the presence of a child and the arrival of a third that influences the probability of being inactive.

The presence of a child or children has a varied effect on employment from country to country. It considerably reduces the probability of working for more than 32 hours per week. The first child has the strongest impact in most countries, except in Belgium, Portugal and Luxembourg, where the effect of the next child or children is quite similar. Conversely the first child has little effect in France, although the impact of the number of children increases with the birth order: a third child has a very negative effect on the probability of working full-time and less impact on working long part-time, while short parttime working, relatively rare, is independent of the number of children.

The probability of working part-time (short or moderate) is not very sensitive to the number of children, except in countries where part-time work is more frequent overall (Figure 1). The presence of a child increases the probability of part-time work, whereas having more than one child is likely to result in withdrawal from employment, whatever the number of working hours. 
Figure 1. Women's labour market situation by number of children, all other things being equal
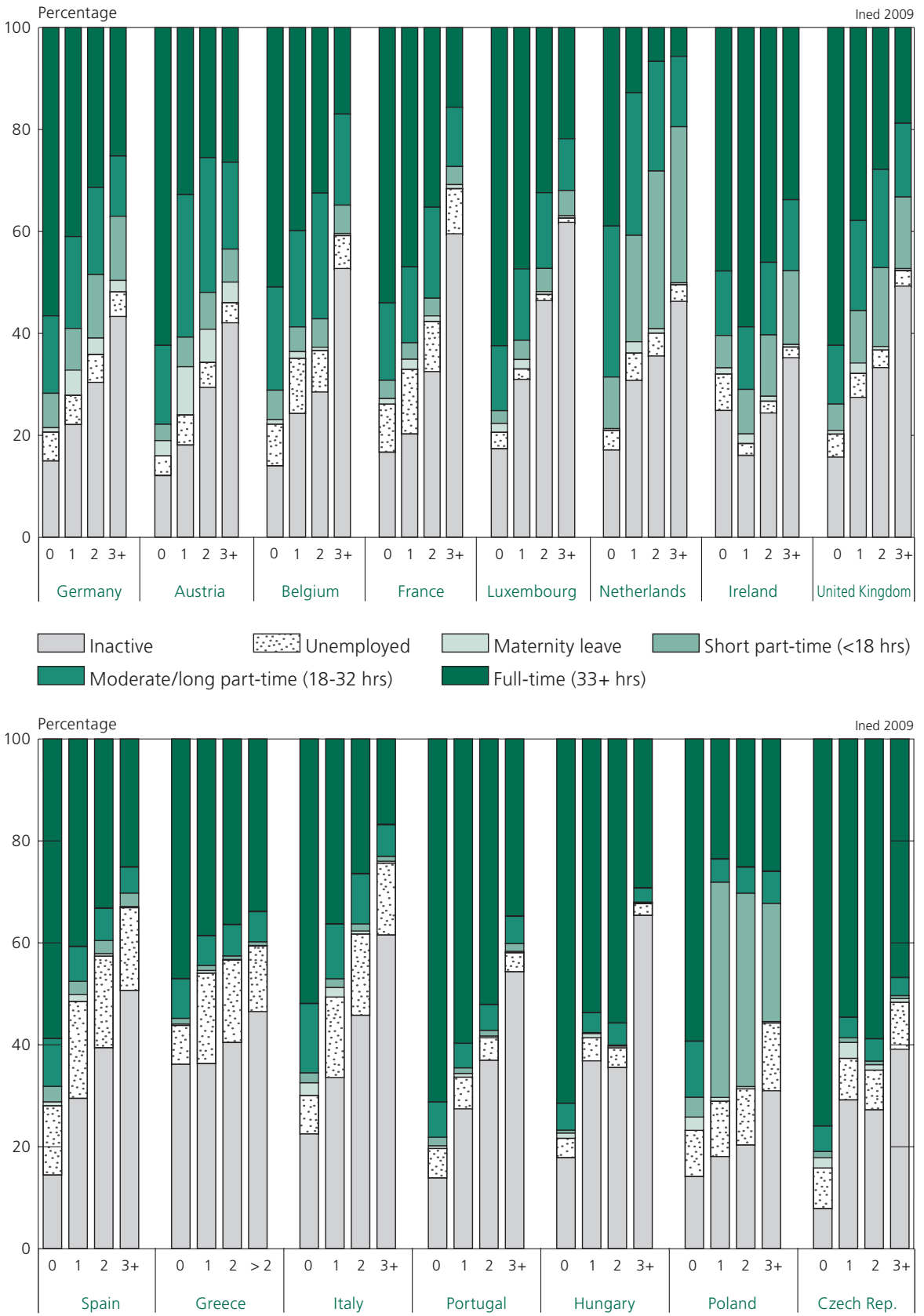

Population: Women aged 20-44

Interpretation: in Belgium, the probability of being inactive is $14 \%$ for a woman without children, and $28 \%$ for a woman with two children, all other things being equal.

Source: Author's calculations based on EU-LFS Surveys,1992-2005. 
In Austria, Germany and the United Kingdom, the probability of working part-time increases up to two children but does not make up for the drop in full-time employment observed for the presence of a first child. Moderate and short part-time work is more frequent with one child than with none but the frequency decreases when there are more than two children, with the heavier domestic burden prompting women to opt more frequently for inactivity rather than moderate part-time working. In the Netherlands, the presence of at least one child strongly reduces the probability of full-time employment, but moderate part-time work is also more frequent among women without children than in other situations. Last, Poland stands out quite clearly from the other Eastern European countries. The first child has a negative impact on full-time employment, while short part-time work is more frequent and over-represented among women with a first child.

The change over time in the impact of the number of children on women's labour force participation is shown in Figure $2^{(5)}$ (see Appendix). It fell during the period in almost all countries. In Belgium the labour market participation of mothers rose more sharply than that of women without children, whose level of inactivity has remained stable. The overall probability of female inactivity has decreased sharply in that country, however, with a growing proportion of women in moderate part-time and full-time employment.

In France, the presence of children has little impact on trends. The decreasing probability of being inactive is counterbalanced mainly by the rise in full-time employment, whatever the number of children and especially for mothers with three children (Figure 2). The pattern is different for mothers of two, however, whose probability of being inactive remained fairly constant up until the early 2000s, contrary to the women in other situations. After this date, their inactivity fell sharply and the frequency of full-time and moderate part-time employment rose, in line with the trend observed for the other family situations. This specific pattern in the behaviour of mothers of two children is probably due to institutional changes dating from 1994, such as the parental leave allowance (Allocation parentale d'éducation) paid for a maximum period of three years to mothers who stop working after the birth of a second child (previously this benefit was paid only for a third child). The delayed increase in labour force participation for these women is therefore consistent with the known effect of these policies on the inactivity of mothers of a second child under three years old (Piketty, 2005). Between 2000 and 2005, the labour force participation of mothers with two children increased. Whatever the family situation, women's full-time employment rose most sharply from the 2000s, as did moderate parttime employment for mothers of two children or more (all other things being equal).

(5) We have not provided this estimate for Ireland and Luxembourg since data were not available for the entire period. 
Figure 2. Change in women's labour market situation by number of children between 1992 and 2005, all other things being equal
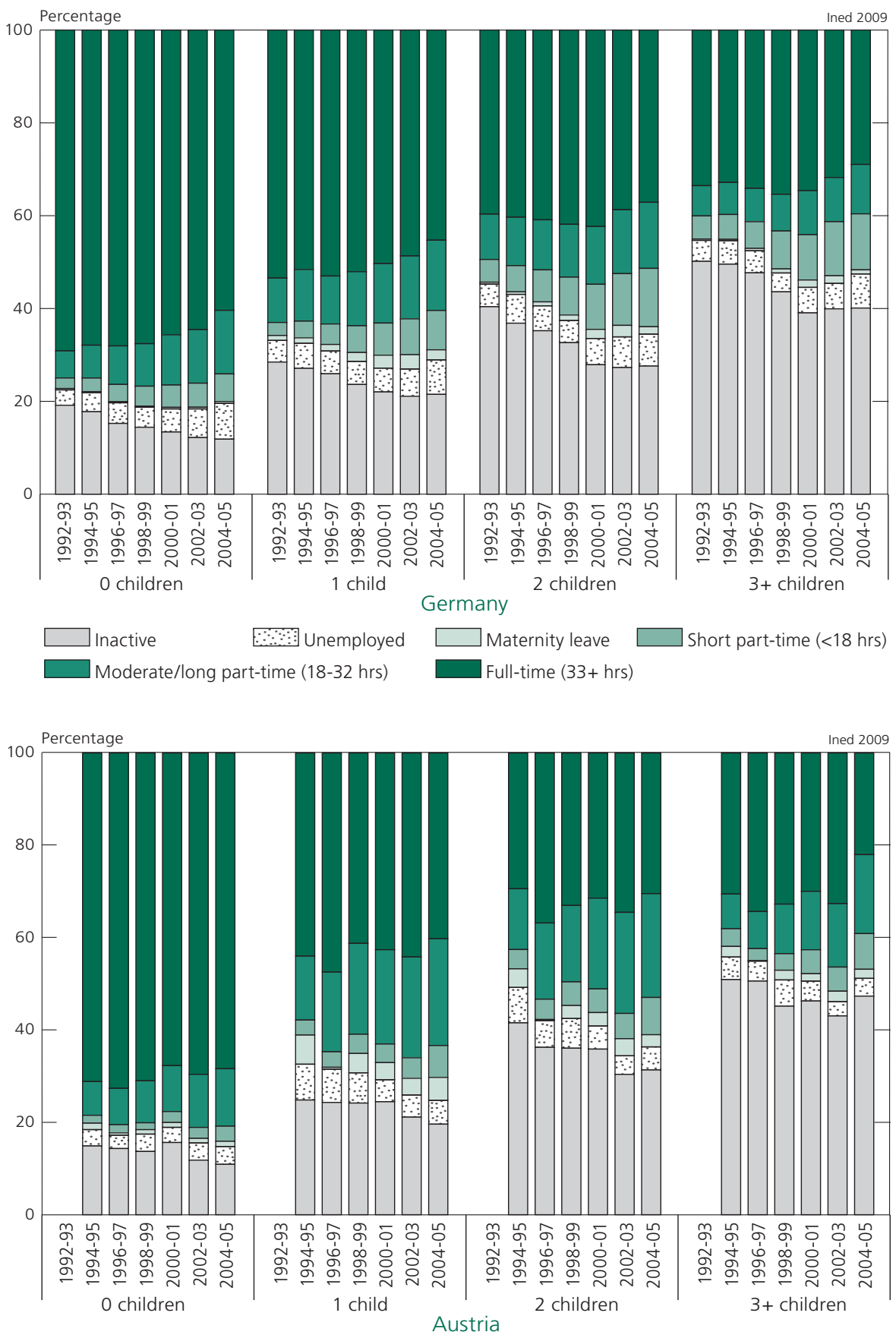

Population: Women aged 20-44.

Interpretation: In Germany, the probability of working full-time for women without children fell from $69 \%$ in 1992-1993 to $60 \%$ in 2004-2005, all other things being equal. Over the same period, the probability fell from $34 \%$ to $29 \%$ for women with three or more children.

Source: Author's calculations based on EU-LFS Surveys,1992-2005. 
Figure 2 (cont'd). Change in women's labour market situation by number of children between 1992 and 2005, all other things being equal
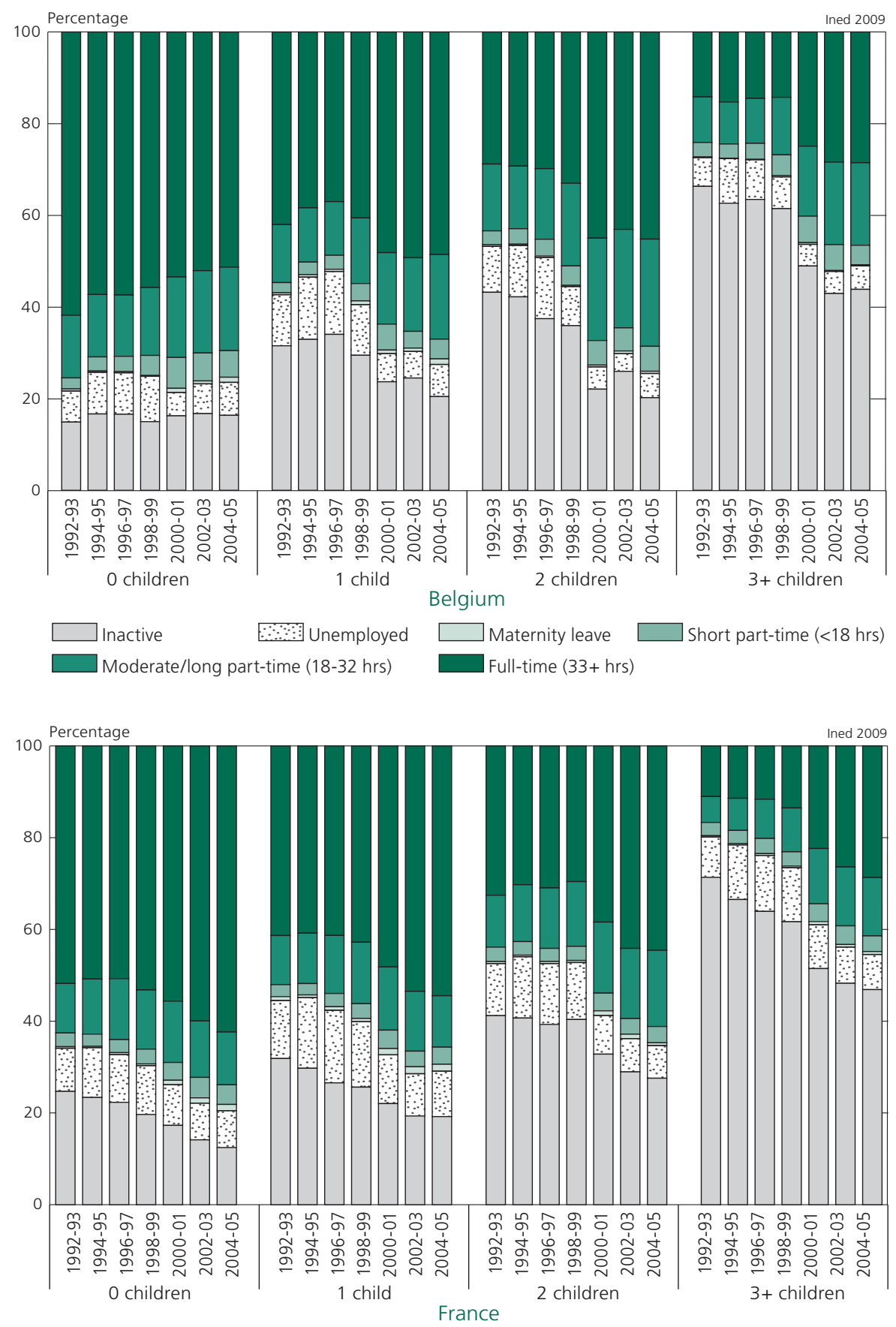

Population: Women aged 20-44.

Source: Author's calculations based on EU-LFS Surveys,1992-2005. 
Figure 2 (cont'd). Change in women's labour market situation by number of children between 1992 and 2005, all other things being equal
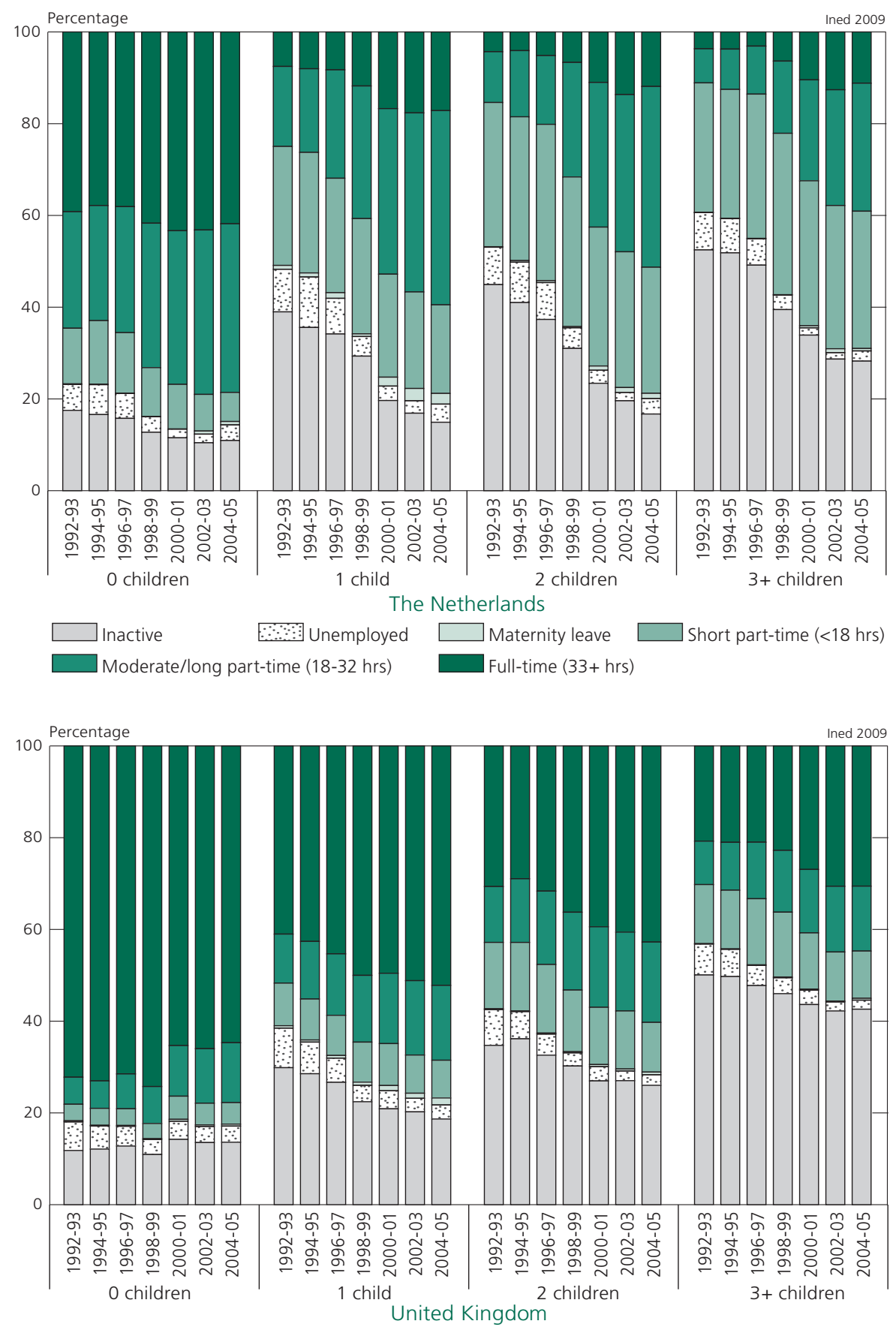

Population: Women aged 20-44.

Source: Author's calculations based on EU-LFS Surveys,1992-2005. 
Figure 2 (cont'd). Change in women's labour market situation by number of children between 1992 and 2005, all other things being equal
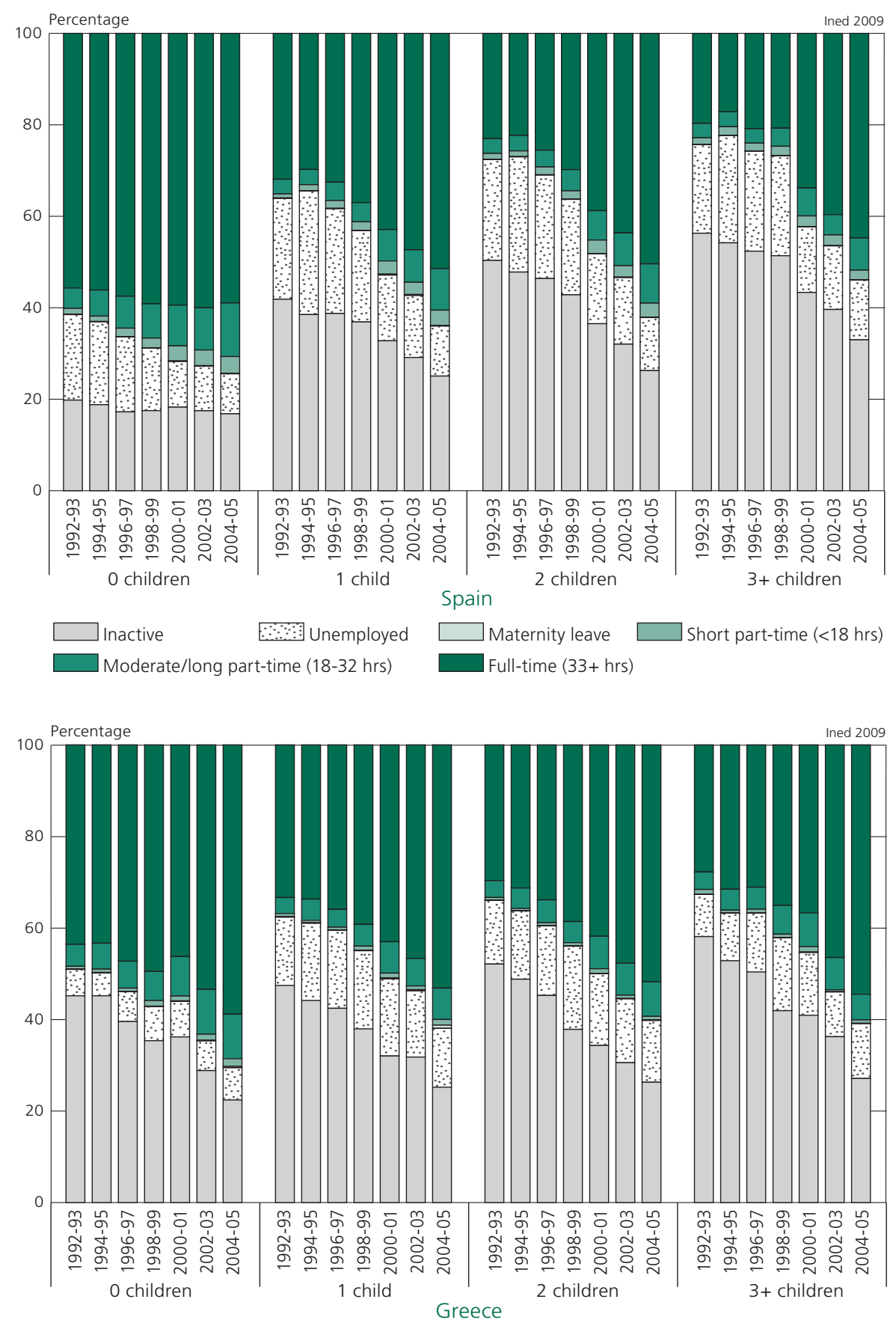

Population: Women aged 20-44.

Source: Author's calculations based on EU-LFS Surveys,1992-2005. 
Figure 2 (cont'd). Change in women's labour market situation by number of children between 1992 and 2005, all other things being equal
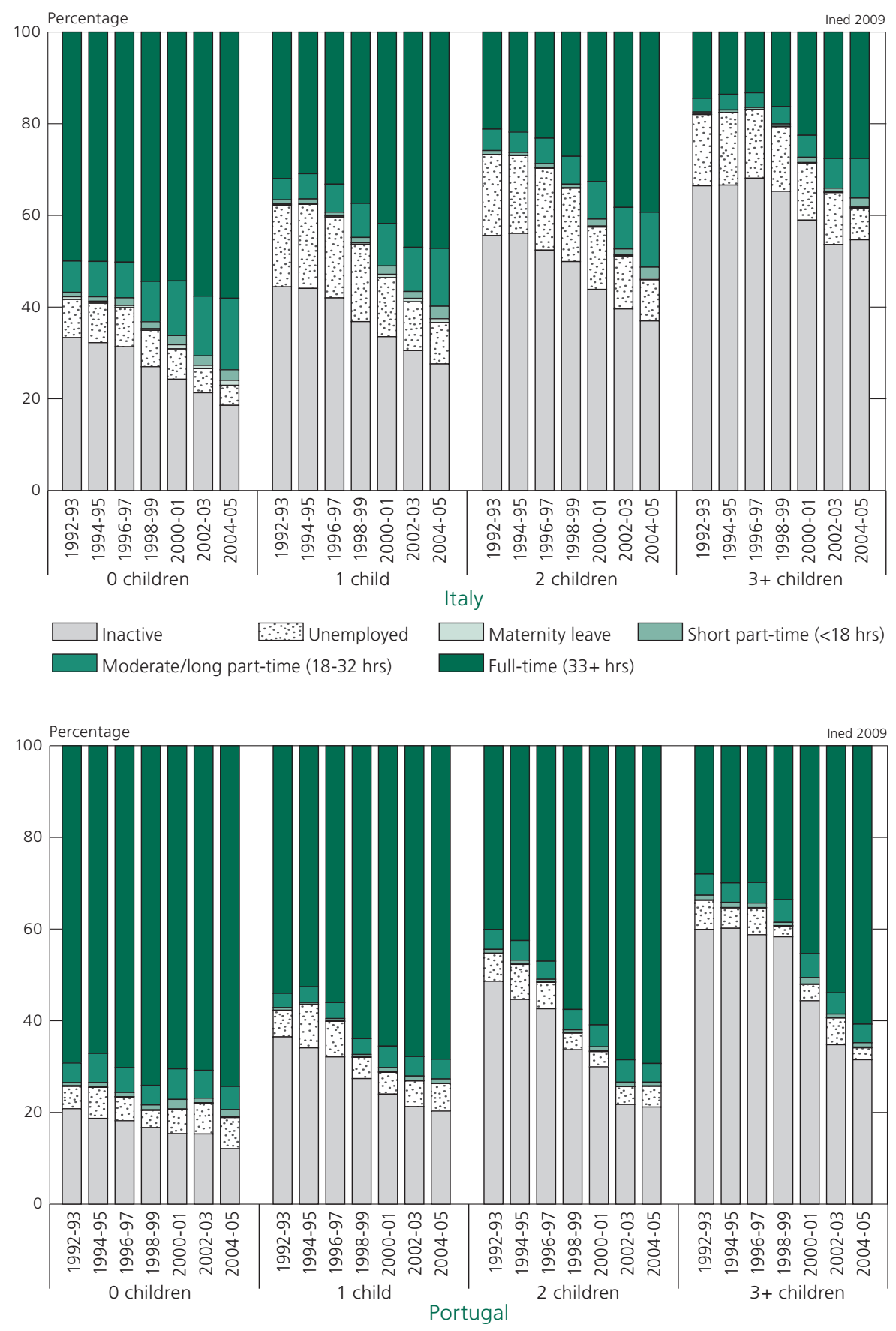

Population: Women aged 20-44.

Source: Author's calculations based on EU-LFS Surveys,1992-2005. 
Figure 2 (cont'd). Change in women's labour market situation by number of children between 1992 and 2005, all other things being equal

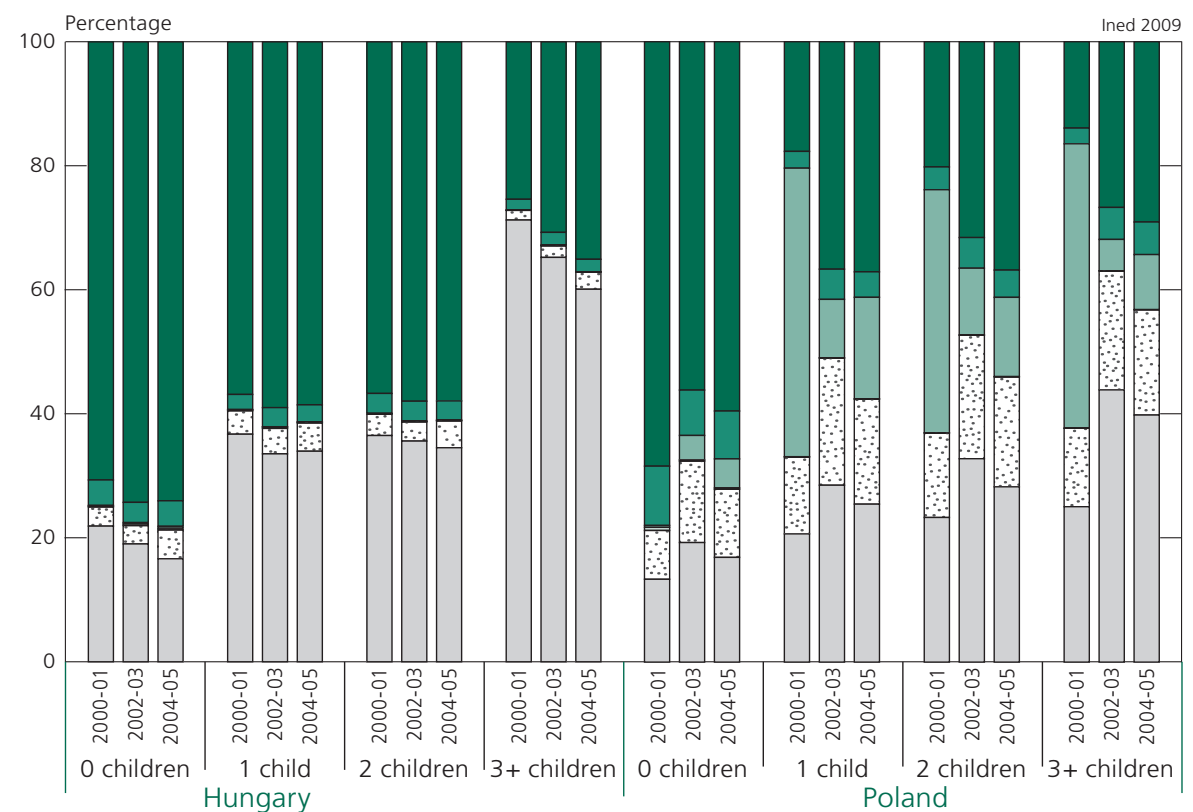

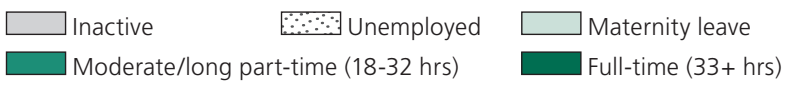

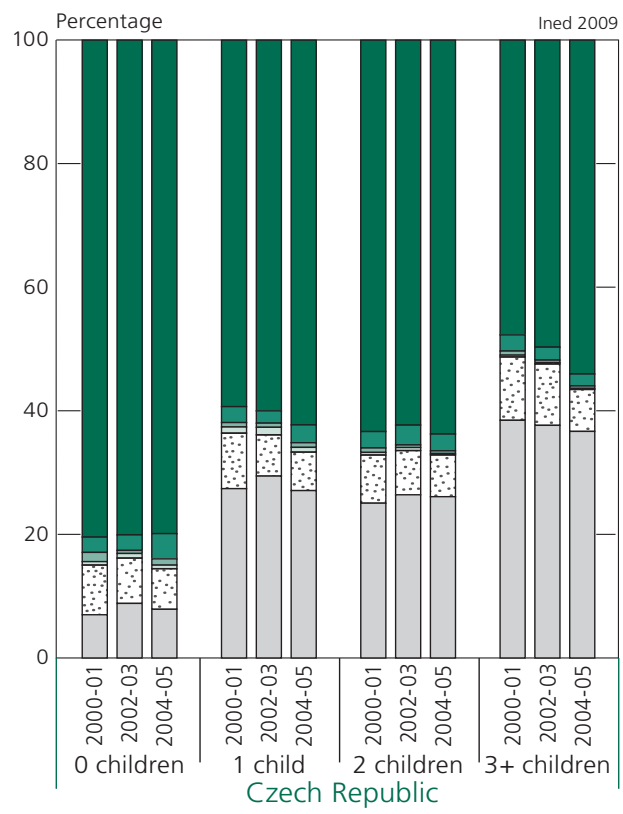

Population: Women aged 20-44.

Source: Author's calculations based on EU-LFS Surveys,1992-2005. 
The trends differ in the other continental European countries. There was a sharper increase in part-time work in Germany and Austria, where the probability of being in moderate or short part-time employment increased at the expense of full-time employment, whatever the family situation. The trend in women's employment is therefore towards fewer working hours, even though full-time work remains the dominant standard.

In the Netherlands, mothers are more likely to work with moderate or short part-time hours rather than full-time. However, their probability of working moderate part-time or full-time rather than short part-time increased during the period. In the United Kingdom, the probability of being in employment also increased sharply for mothers, many more of whom now work full-time, whereas for women without children the probability of being in full-time work decreased.

In southern European countries we observe major changes in women's labour market situations according to the number of children, all other things being equal. First, inactivity decreased sharply, while employment, mostly full-time, increased. Trends vary, however, with disparities according to the number of children. In Greece and Italy, employment behaviour follows a similar pattern for all women. In Portugal and Spain, on the other hand, variations are small for women without children but far greater when children are present. Inactivity fell sharply for mothers while their probability of working full-time increased considerably.

It is not easy to interpret these trends, however. On the one hand, the specific increase in labour force participation of mothers appears to reflect more favourable conditions for reconciling work and family life. On the other hand, the sharp increase in the number of women without children and the smaller number of children per mother, as mentioned in the previous section, may signify a greater selection of women in employment (on the part of women as well as employers). Only women able to reconcile their working lives with the presence of children are in a position to decide to have a child, or to not postpone conception. The increase in employment, for a given number of children, may thus reflect a growing selection of women who have control over these factors.

\section{A variable effect on women's employment by age of youngest child}

The effect of the age of the youngest child varies by country. Labour force participation varies little with the age of the youngest child in Belgium and the Mediterranean countries (Figure 3). In France, the three-year threshold is more pronounced than in other countries because of the institutional system that combines financial support for mothers of under-threes who stop work, with extensive and early nursery school provision (see following section). A share of the French women who return to work after two years choose moderate part-time employment, as is the case in Belgium. 
Figure 3. Labour market situation of mothers by age of youngest child, all other things being equal
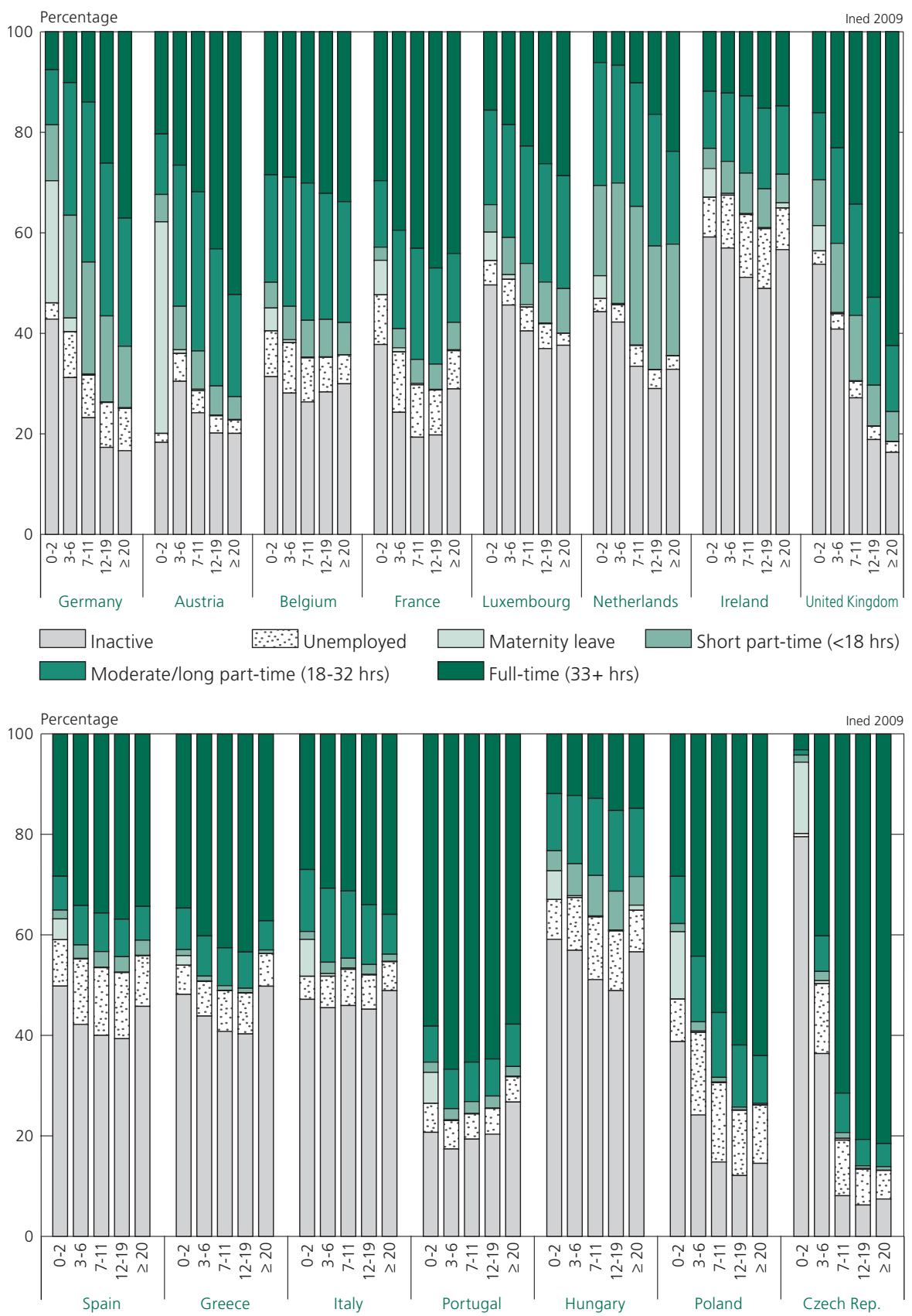

Population: Women aged 20-44 with at least one dependent child.

Interpretation: In the United Kingdom, the probability of being inactive is $54 \%$ for mothers whose youngest child is under three, and $40 \%$ if the child is aged 3-6 years, while the probability for these mothers of being in full-time employment is $16 \%$ and $23 \%$, respectively, all other things being equal.

Source: Author's calculations based on EU-LFS Surveys,1992-2005. 
The impact of the age of the youngest child is strongest in Eastern Europe and the United Kingdom. In Eastern Europe, as the youngest child grows older, the probability of being inactive decreases while the probability of being active full-time increases. There is little effect on part-time work, which remains rare. The probability of being inactive or on parental leave with a child under three is far stronger here than elsewhere. The end of parental leave and the child's entry into the educational system at age three appears to be a determining stage since the probability of the mother remaining inactive falls sharply after that age, and that of being in full-time employment increases. Later changes are less pronounced. In the United Kingdom, the effect is strong but progressive across the child's life cycle. There is a clear increase in the volume of weekly working hours as the child grows older: the probability of being in moderate part-time work increases until the child enters primary school (age 6-7), after which it is full-time employment that rises most sharply. The age of the child has a similar but more limited effect in the Netherlands, Germany and Austria.

\section{Variable impact of mother's age at first birth}

The mother's age at first birth is a factor that differentiates the behaviour of women with at least two children (Figure 4). This variable has a two-fold impact. On the one hand, it reflects the age of the eldest child by construction and therefore the age difference between the eldest and youngest child. An older mother at the birth of the first child therefore implies, for a given survey date, a younger first child and a smaller age difference with the second child, for whom we would expect a negative impact on the mother's labour force participation. On the other hand, first birth postponement may enable mothers to acquire more work experience prior to the birth of their children, and the value of that experience may have a positive impact on their labour force participation. In this case the institutional environment will be a determining factor. We expect the first effect (negative incidence) to prevail in contexts where there are persistent problems in obtaining child care.

In a first set of countries, higher age at first birth clearly leads to a lesser probability of being inactive, all other things being equal. That holds true in the Netherlands, where the probability of short and moderate part-time employment increases in parallel with postponement of childbearing. Nevertheless, mothers are more likely to opt for part-time work because the low relative age of the eldest child probably leads to constraints on working hours. We find a similar effect of age at first birth in Italy, although first birth postponement in that country has a positive effect on the frequency of fulltime and moderate part-time employment.

In the United Kingdom and Belgium, the frequency of inactivity is not a monotonic function of the woman's age at first birth. A woman aged 25-29 at the birth of her first child is less likely to be inactive than if the child was born 
Figure 4. Labour market situation of mothers by age at first birth, all other things being equal
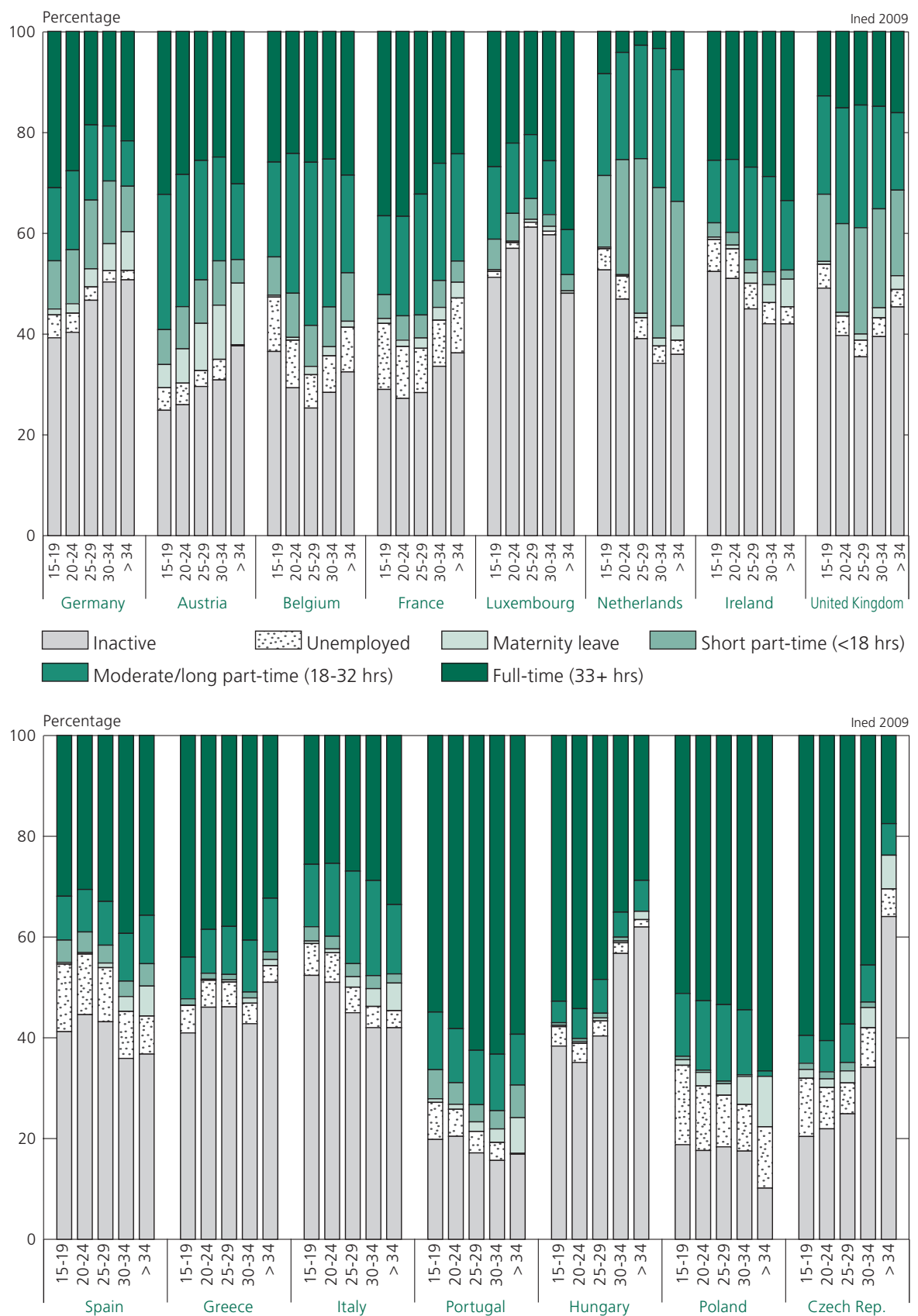

Population: Women aged 20-44 with at least two dependent children.

Interpretation: In the Netherlands, the probability of being inactive is $47 \%$ when the mother is aged 20-24 at first birth, and 34\% when she is aged 30-34. The probability of being in short or moderate part-time employment is highest in the latter age group, all other things being equal. Source: Author's calculations based on EU-LFS Surveys,1992-2005. 
Figure 5. Women's labour market situation in relation to that of their spouse, all other things being equal
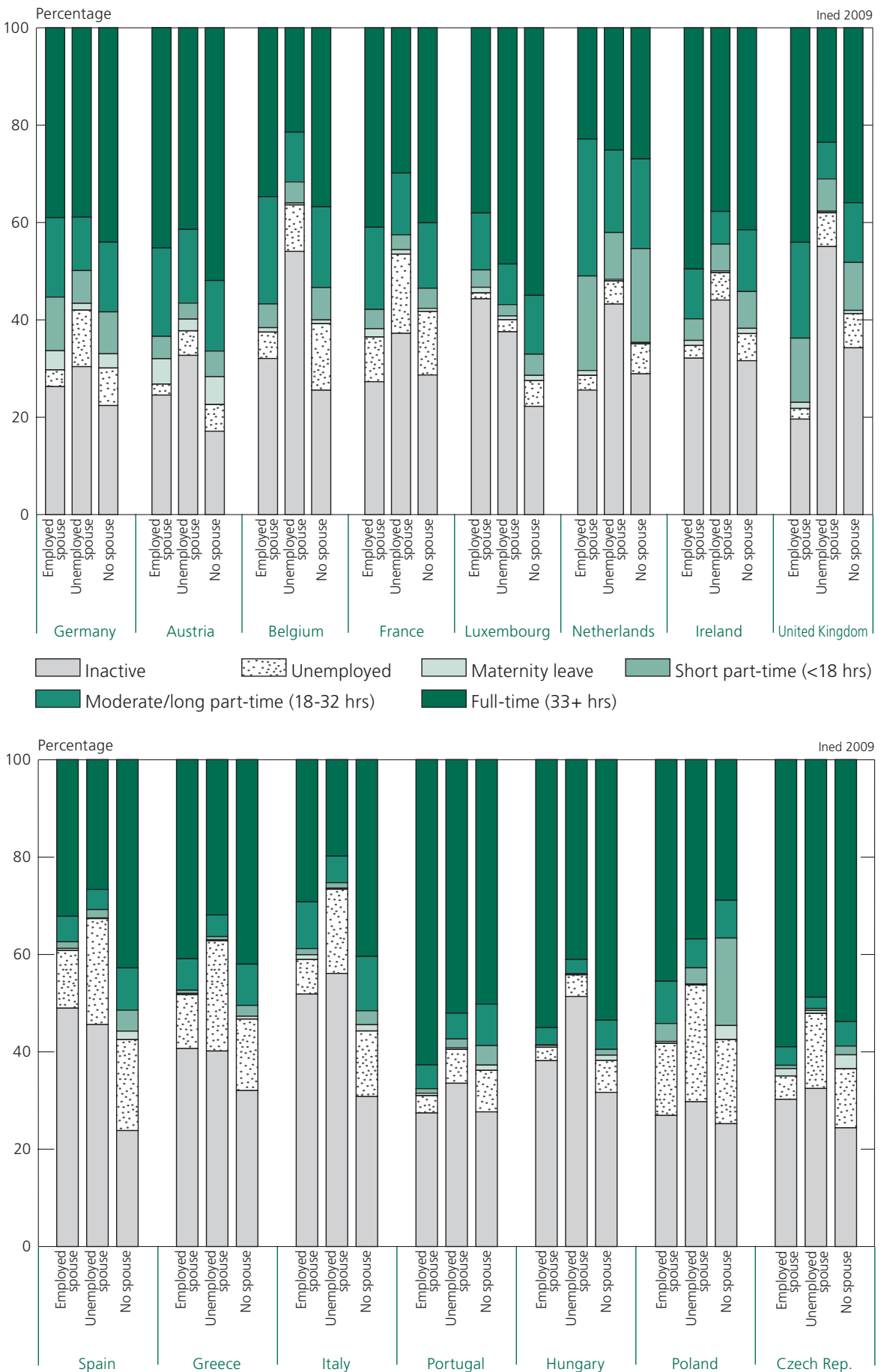

Population: Women aged 20-44

Interpretation: In Spain, the probability for a woman of being inactive is $49 \%$ when her spouse is employed, $46 \%$ when he is unemployed and $29 \%$ when she is single, all other things being equal. 
earlier or later. It is mainly the probability of part-time work that increases up to age 29 and then falls. When first births are postponed to age 30 they appear to increase the likelihood of opting for part-time work instead of inactivity between ages 18 and 30, but the opposite is true when the first child is postponed beyond age 30 .

An even clearer trend of this type is observed in Germany, Hungary, the Czech Republic and Luxembourg, and to a lesser extent in Austria, France and Greece. We can presume that the age difference between children is a determining factor in mothers' labour force participation. It might also be the case that women who delay childbearing are in a more comfortable financial position, and that the decision to stop work after a birth entails less economic hardship. In France, the later arrival of the first child increases the probability of moderate part-time work.

\section{Stronger impact of the presence of a spouse in Mediterranean countries}

The presence of a spouse and his employment situation are important factors that influence the labour market behaviour of women (Figure 5). Whatever his employment status, the presence of a spouse increases the probability of inactivity for women in Spain, Italy and Luxembourg, reflecting a fairly traditional division of labour between men and women, independently of the presence of children. In most other countries it is the fact of the spouse being employed that influences the activity of women, and the probability of being inactive is all the higher if the spouse himself is unemployed. Women whose partner is unemployed are nonetheless more likely to be seeking work.

\section{Discussion}

While the male employment rate has stagnated since the early 1990s, and even fallen in some countries, women's employment continued to rise until 2005 (Table 1). Growth varied between countries and was especially strong in Ireland and Spain. In 2005, employment rates were higher in the northern European countries than in the Mediterranean and Eastern European ones, where a parallel increase was observed in the number of women aged 20-44 with no children or only one child.

By modelling employment situations by family characteristics we were able to identify the relationships and trends specific to certain countries or certain family situations. The main results are summarized in Table 3, supplemented by Table 4, which presents the national institutional contexts that may explain the changes observed.

The model highlights the important changes affecting mothers in Belgium, Spain, Portugal, Poland, the Netherlands and the United Kingdom. Despite the increase in part-time employment, its role in the work-life balance varies between countries. It is very widespread in the Netherlands, the United Kingdom 
and Germany, but still fairly rare in Eastern and southern Europe. The frequency of part-time employment is generally insensitive to the number of children (except in the Netherlands) and, like full-time employment, more strongly influenced by the age of the youngest child.

These results confirm the differences in women's employment "regimes" already identified in part by earlier studies (Kempeneers and Lelièvre, 1993; Rubery et al., 1996; Thévenon, 1999; Gornick et al., 1997; Thévenon, 2006) which highlight the diversity of adjustments in employment behaviour according to family situation. The similarities and differences observed between countries only partially coincide with the welfare state typologies identified in the early 1990s (Esping-Andersen, 1990). The explanation must therefore be sought in institutional specificities other than those resulting from the overall welfare state rationale. We have identified new tendencies in certain European regions, notably contrasting trends in continental Europe.

France and Belgium continue to share similar characteristics, even though the employment rate of Belgian women is $4 \%$ below that of French women. The majority of women's jobs are full-time and the first child has little impact on the probability of having a full-time job, unlike the third child who has the greatest impact on labour market behaviour. The inactivity rate falls rapidly with the child's age as soon as he or she enters the preschool system, especially in France. In 2006, more than 40\% of children under age three were enrolled in formal childcare in both these countries, usually full-time (more than 30 hours per week). Above age three, the vast majority of childen attend nursery school, where the opening hours, as in primary school, are compatible with those of working parents. Part-time work is not, therefore, a widely used method for managing the work-life balance, even though the proportion of mothers opting for reduced working hours has increased since 1992. In all cases, part-time work is fairly long, ranging from 18 to 32 hours.

There are differences between France and Belgium, however, since the effect of a single child on the full-time activity of women is weaker in France, while the increase in family size to two children, and especially three, has a greater impact. The behavioural structure here matches a relatively well-known set of institutional characteristics (Thévenon, 1999; Adema and Thévenon, 2008). First, parents with one child benefit from strong support in the form of childcare services or financial assistance if they use a registered childminder or nanny. Second, benefits are paid to parents who stop working after the birth of a second or third child. This support probably explains the higher rate of inactivity among women with one child aged under three years and the sharp decline in inactivity after the child's third birthday. Furthermore, the income tax system tends to favour households whose income is generated by one, rather than two, working parents (Legendre and Thibault, 2007). The "family quotient" system leads to additional tax reductions from the third child onwards, which further benefits parents with only one working partner. 


\begin{tabular}{|c|c|c|c|c|c|c|c|c|}
\hline \multirow{2}{*}{ 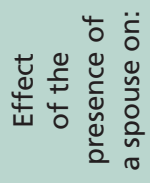 } & \multicolumn{2}{|c|}{ 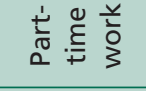 } & 1 & 1 & 1 & 1 & $\|$ & $\begin{array}{l}1 \\
1\end{array}$ \\
\hline & \multicolumn{2}{|c|}{ 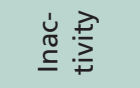 } & $\ddagger$ & $\ddagger$ & $\ddagger$ & $\|$ & $\stackrel{+}{+}+$ & 1 \\
\hline \multicolumn{3}{|c|}{ 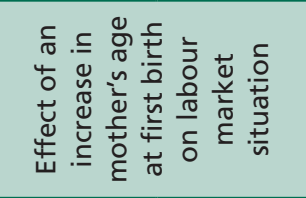 } & 1 & 1 & + & + & 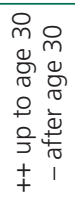 & $\ddagger$ \\
\hline \multirow{3}{*}{ 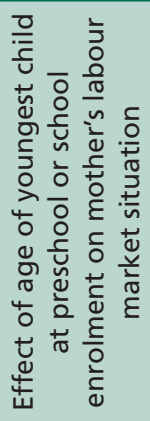 } & \multicolumn{2}{|c|}{ 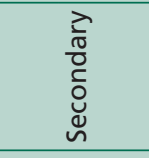 } & + & + & " & $\|$ & + & + \\
\hline & \multicolumn{2}{|c|}{ 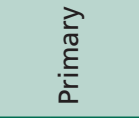 } & + & + & + & + & + & $\stackrel{+}{+}$ \\
\hline & \multicolumn{2}{|c|}{ 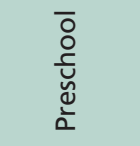 } & $\stackrel{+}{\ddagger}$ & $\stackrel{+}{+}$ & + & $\ddagger$ & + & + \\
\hline \multicolumn{3}{|c|}{ 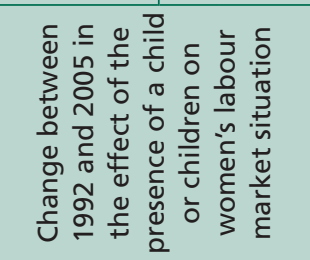 } & 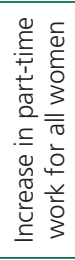 & 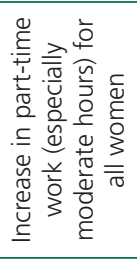 & 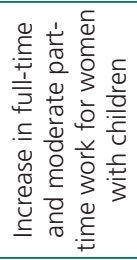 & 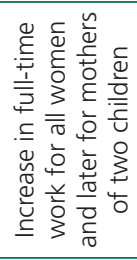 & & 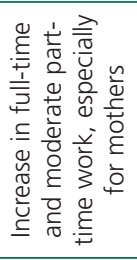 \\
\hline \multirow{6}{*}{ 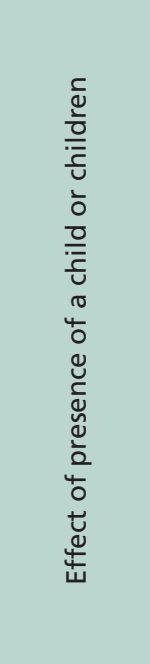 } & \multirow{3}{*}{ 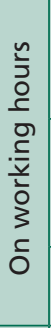 } & 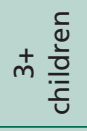 & I & 1 & I & 1 & $\begin{array}{l}1 \\
1 \\
1\end{array}$ & ॥ \\
\hline & & $\sim \frac{\frac{\varrho}{0}}{\frac{0}{\bar{c}}}$ & 1 & 1 & " & $\|$ & " & $\begin{array}{l}1 \\
\text { I }\end{array}$ \\
\hline & & $-\frac{\overline{0}}{\bar{z}}$ & $\begin{array}{l}1 \\
\text { I }\end{array}$ & $\begin{array}{l}1 \\
1\end{array}$ & $\|$ & $\|$ & 1 & $\begin{array}{l}1 \\
1\end{array}$ \\
\hline & \multirow{3}{*}{ 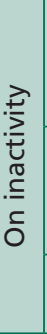 } & 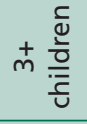 & + & + & $\begin{array}{l}+ \\
+ \\
+\end{array}$ & $\stackrel{+}{+}+$ & + & $\ddagger$ \\
\hline & & 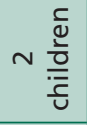 & + & + & ॥ & + & + & + \\
\hline & & $-\frac{\overline{0}}{\bar{T}}$ & + & + & + & $\|$ & $\ddagger$ & $\stackrel{+}{+}$ \\
\hline \multicolumn{3}{|c|}{ 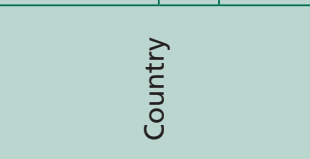 } & 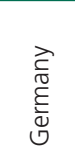 & 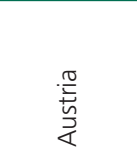 & $\frac{\xi}{\frac{\xi}{\bar{D}}}$ & 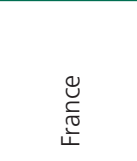 & 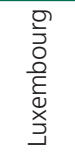 & 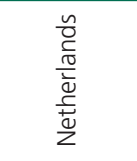 \\
\hline
\end{tabular}


INCREASED WOMEN'S LABOUR FORCE PARTICIPATION IN EUROPE

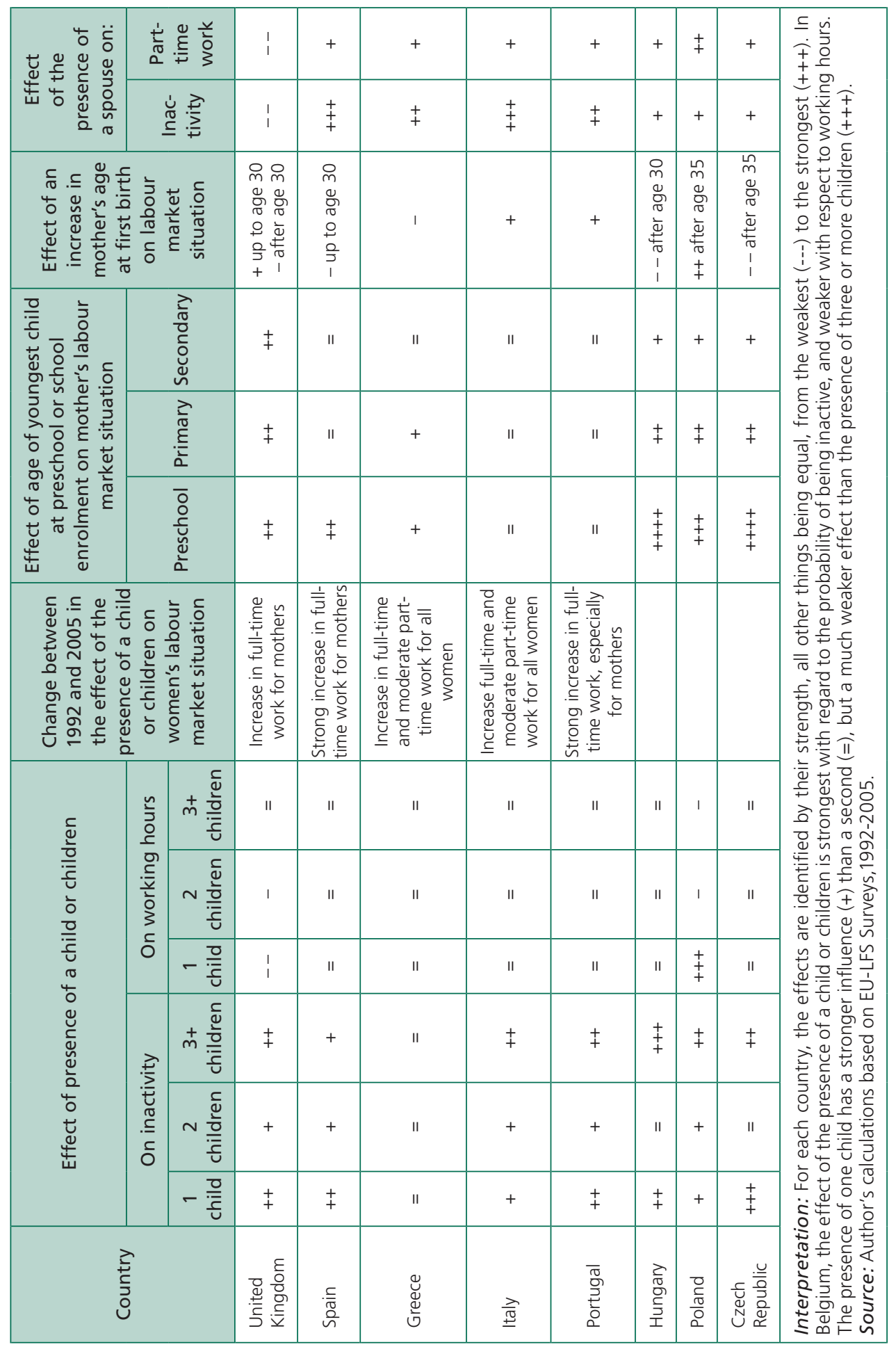


Germany and Austria have employment rates above the EU-15 average, but these have risen relatively slowly since 1990. In both these countries, the probability of being active decreases gradually with the size of the household and rises with the age of the youngest child. Mothers with one child under three are much more frequently inactive here than in the preceding case, notably because more mothers take parental leave. They benefit from a longer period of paid maternity leave from the first child and far less frequently use external childminding services than French or Belgian mothers, or do so for a much shorter time (Table 4). The return to work is gradual and is generally timed to coincide with the youngest child's entry into primary school or, most commonly, secondary school. Full-time work is far more frequent when the child is enrolled in primary school, but still less so than in France or in Belgium, probably due to the organization of the school schedule into long half-days and the still inadequate provision of childcare outside school hours. The constraints related to the child's life cycle explain why the decision not to work is more probable when there is a small age difference between the children. In this context, long part-time work allows a large proportion of mothers (more in Austria than in Germany) to work after the birth of the first child. In both countries, it is above all the frequency of moderate and short part-time work (in the case of Germany) that has increased at the expense of full-time work whatever the family situation, creating the conditions for a potential "marginalization" of women's employment situations. Indeed, a growing polarization is becoming apparent, more so in Germany than in Austria with, on the one hand, women who remain childless (or childless for longer) and who are much more likely to be in full-time employment and, on the other, women who interrupt their careers for a fairly long period after the birth of a child and then return to moderate or short part-time jobs.

The Netherlands is quite different from the preceding cases because of the widespread existence of part-time work in that country, whether or not children are present. Moderate part-time work is the form of employment that increased the most during the period, whatever the family configuration, whereas short part-time work decreased. The female employment rate rose sharply between 1992 and 2005, and more for mothers than for women without children, indicating a favourable context for reconciling work and family life, as is also shown by the sharp increase in take-up of childminding services for young children, although the hours involved are relatively short (17 hours per week on average). The decision to work often depends on the family situation, however. The presence of at least one child considerably reduces the probability of working, especially full-time. Here the volume of hours clearly serves as an adjustment variable in relation to family size, since the probability of moderate part-time working decreases with the number of children while the frequency of short part-time work increases. Full-time employment, which also rose over the period, increases above all when the child enters secondary school. The relatively short school days certainly account in part for the low frequency of 
full-time employment for women with children and for the preponderance of moderate part-time employment. This environment may explain the fairly sharp, and apparently growing, polarization between women without children on the one hand, (a particularly large proportion of women in these countries) who are more likely to work full-time, and mothers, on the other, who are larger contributors to the increase in moderate part-time employment. In this context, the timing of the first birth, which is also later here than in other European countries, appears to be a truly discriminating variable in the worklife balance.

In terms of the work-life balance adjustments achieved by working parttime, the United Kingdom resembles the Netherlands (Thévenon, 2006). Fulltime employment is nonetheless more frequent in the UK, despite a considerable fall-off, albeit gradual, as family size increases. The number of children does not greatly affect part-time work, but the age of the youngest child does. The entry of the youngest child into preschool favours women's return to work in all types of employment. Constraints on women's schedules explain the limited number of working hours, since young children are only accepted in preschool for four to five hours per day. Entry into primary school, and especially secondary school, favours the extension of women's working hours. Last, we observed a reduction in the differences in employment rates between women with and without children over the period, as well as a very slight increase in the proportion of women without children. This smoothing of disparities is probably due to the introduction of financial benefits and the development of childcare provision since the mid 1990s, which has benefited working mothers (OECD, 2004).

The Mediterranean countries (Spain, Italy, Greece) share several characteristics. In the early 1990s, female employment rates were the lowest in Europe, but they have since risen sharply and the gap between these and other European countries has narrowed. Full-time employment remains the norm, whatever the household size. The existence of a spouse, whether employed or not, increases the probability for women of being inactive, highlighting the persistent traditional male-female division of labour. The presence of children has the same impact on women's employment, and especially the birth of the first child (except in Greece where the number of inactive women without children is already high). The number and ages of the children have only a limited impact on the labour market behaviour of Greek women. For Italian and Spanish women, on the other hand, while the child's age has little impact, the number of children is the determining variable for labour force participation. A large proportion of women enter employment, usually full-time, when the child reaches the age of three. From the mid-1990s, female employment rose more sharply in Spain than in other Mediterranean countries. More mothers now work full-time and benefit from more widespread preschool provision than at the beginning of the period, since organized childcare has developed 


\begin{tabular}{|c|c|c|c|c|c|c|c|c|c|}
\hline \multirow{3}{*}{ 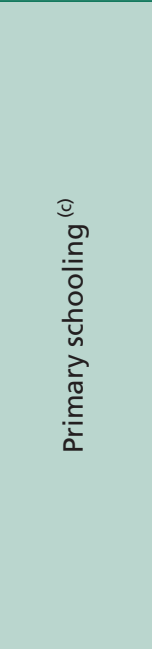 } & \multirow{2}{*}{$\begin{array}{l}\frac{\pi}{0} \\
\frac{0}{0} \\
\circ \\
\frac{c}{u}\end{array}$} & 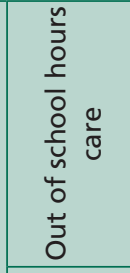 & 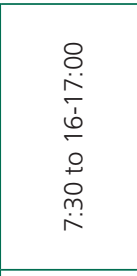 & 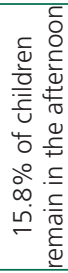 & 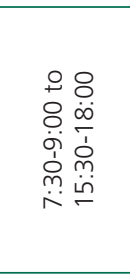 & 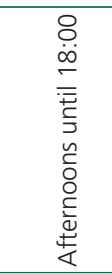 & 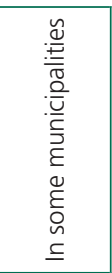 & 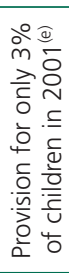 & 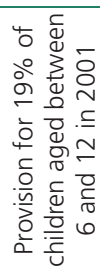 \\
\hline & & 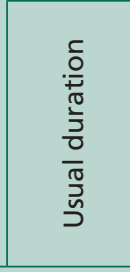 & $\begin{array}{l}0 \\
0 \\
0 \\
m \\
\dot{m} \\
\dot{m} \\
\dot{0} \\
\dot{0} \\
\dot{m} \\
\dot{n} \\
\stackrel{m}{=}\end{array}$ & 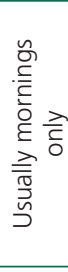 & 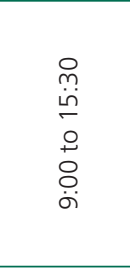 & 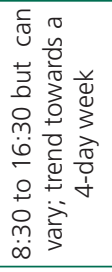 & 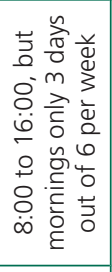 & 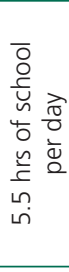 & 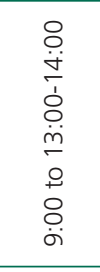 \\
\hline & \multicolumn{2}{|c|}{ 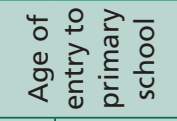 } & 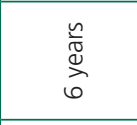 & $\underset{0}{\stackrel{n}{\pi}}$ & 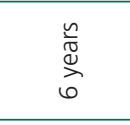 & $\begin{array}{l}\frac{n}{\sqrt{\pi}} \\
\stackrel{2}{0}\end{array}$ & $\begin{array}{l}\frac{n}{\sqrt{\pi}} \\
\stackrel{2}{*} \\
6\end{array}$ & 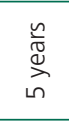 & 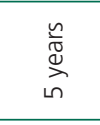 \\
\hline \multirow{6}{*}{ 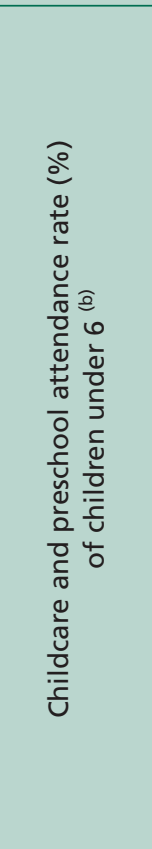 } & \multirow[t]{3}{*}{ 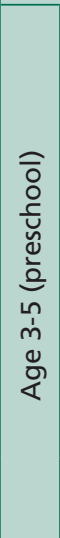 } & 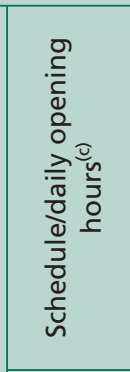 & 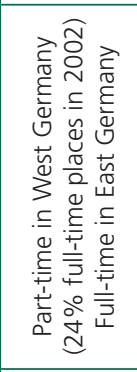 & 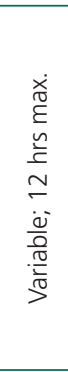 & 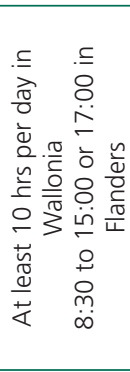 & 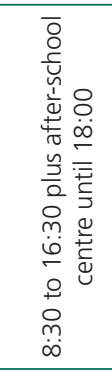 & 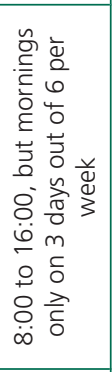 & 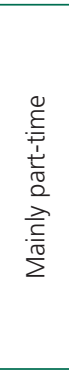 & 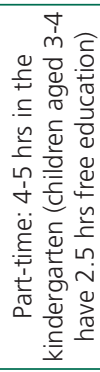 \\
\hline & & 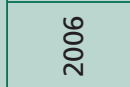 & ஓे & $\stackrel{\infty}{\stackrel{\infty}{\perp}}$ & $\begin{array}{l}\infty \\
\text { ğ }\end{array}$ & $\stackrel{\circ}{\circ}$ & $\begin{array}{l}\stackrel{\sim}{\sim} \\
\stackrel{n}{\infty} \\
\infty\end{array}$ & $\stackrel{\infty}{\stackrel{\infty}{n}}$ & மீ \\
\hline & & 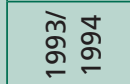 & $\stackrel{\infty}{\wedge}$ & $\stackrel{\llcorner}{\wedge}$ & นn & 우 & 1 & 1 & 8 \\
\hline & \multirow{3}{*}{ 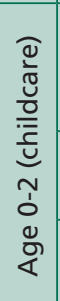 } & 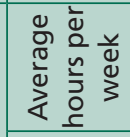 & $\approx$ & $\stackrel{n}{\sim}$ & $\stackrel{\mathrm{m}}{ }$ & ○ & $\bar{m}$ & 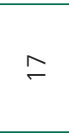 & $\stackrel{\infty}{-}$ \\
\hline & & ஜ̊ & $\stackrel{\sim}{\sim}$ & $\stackrel{n}{\circ}$ & 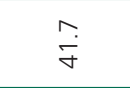 & 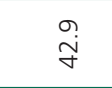 & $\stackrel{\forall}{\dddot{r}}$ & $\stackrel{\sigma}{m}$ & ิें \\
\hline & & $\begin{array}{l}\text { ले ठू } \\
\text { ळ̆ }\end{array}$ & 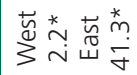 & $m$ & ஓे & $\stackrel{m}{\sim}$ & 1 & $\infty$ & $\sim$ \\
\hline \multirow{2}{*}{ 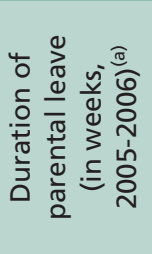 } & \multicolumn{2}{|c|}{ 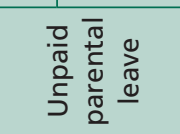 } & กิ & 1 & 1 & 1 & I & $\stackrel{\searrow}{\sim}$ & $\stackrel{\bullet}{\sim}$ \\
\hline & \multicolumn{2}{|c|}{ 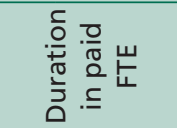 } & $\stackrel{+}{\rightleftarrows}$ & $\stackrel{\infty}{\stackrel{\infty}{\sim}}$ & $\stackrel{\sim}{\sim}$ & 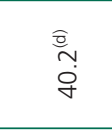 & I & I & 1 \\
\hline \multicolumn{3}{|c|}{ 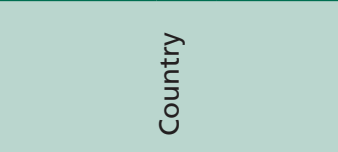 } & 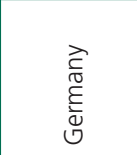 & 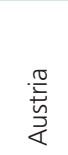 & $\begin{array}{l}\frac{\varepsilon}{3} \\
\frac{\bar{J}}{\bar{D}} \\
\frac{D}{D}\end{array}$ & 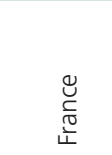 & 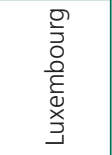 & 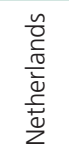 & 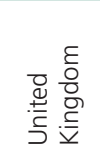 \\
\hline
\end{tabular}




\begin{tabular}{|c|c|c|c|c|c|c|c|c|c|c|}
\hline \multirow{3}{*}{ 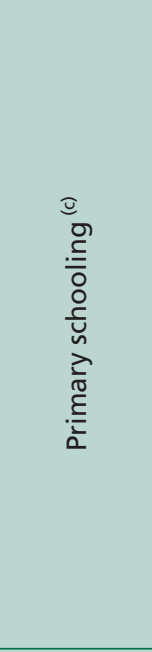 } & \multirow{2}{*}{ 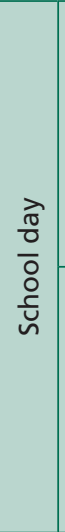 } & 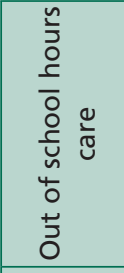 & 1 & 1 & 1 & 1 & 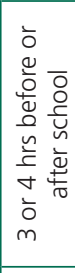 & 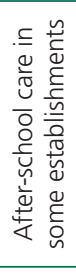 & & \multirow{2}{*}{ 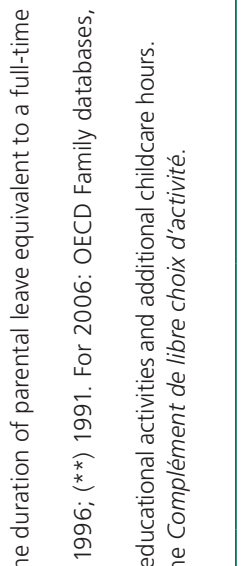 } \\
\hline & & $\begin{array}{l}\frac{c}{0} \\
\frac{0}{0} \\
\frac{0}{5} \\
\frac{0}{0} \\
\frac{\pi}{3} \\
5 \\
5\end{array}$ & 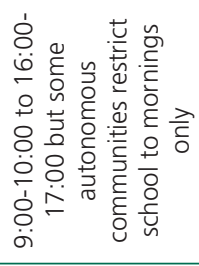 & 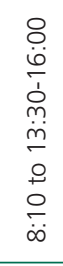 & 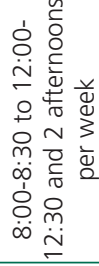 & $\begin{array}{l}0 \\
m \\
i \\
i \\
o \\
0 \\
m \\
\dot{0} \\
\dot{0} \\
\dot{o}\end{array}$ & $\begin{array}{l}8 \\
0 \\
\text { in } \\
\\
+ \\
0 \\
0 \\
\dot{\infty}\end{array}$ & 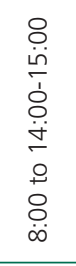 & 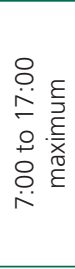 & \\
\hline & \multicolumn{2}{|c|}{ 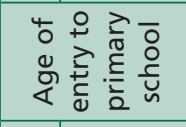 } & 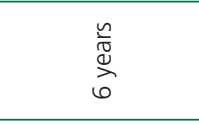 & $\begin{array}{l}\frac{\tilde{\sigma}}{\sigma} \\
\stackrel{\Xi}{\sigma} \\
\sigma\end{array}$ & 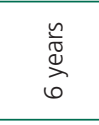 & 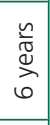 & $\begin{array}{l}\frac{\tilde{\sigma}}{\pi} \\
\stackrel{\Xi}{\Perp} \\
\llcorner\end{array}$ & 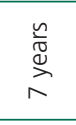 & $\begin{array}{l}\frac{n}{\sigma} \\
\stackrel{\widetilde{\sigma}}{\sigma}\end{array}$ & \multirow{10}{*}{ 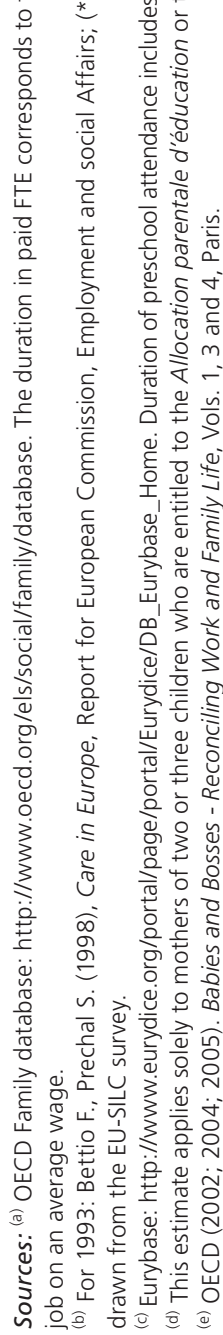 } \\
\hline \multirow{6}{*}{ 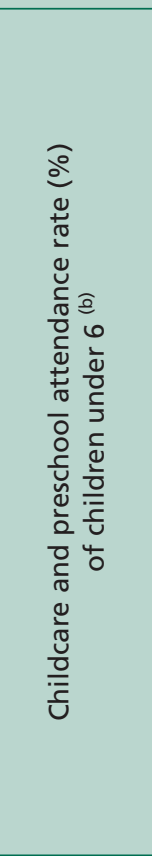 } & \multirow[t]{3}{*}{ 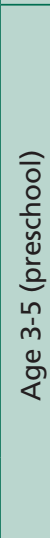 } & 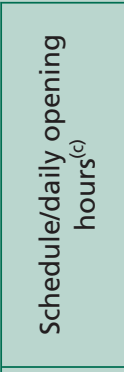 & 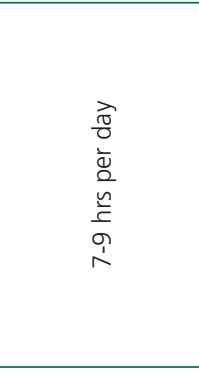 & 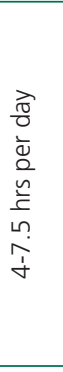 & 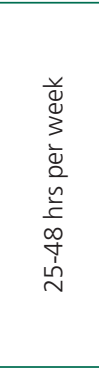 & 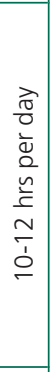 & 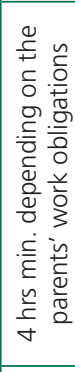 & 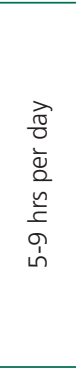 & 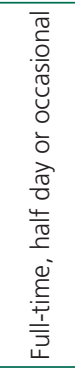 & \\
\hline & & ஜ̊ & $\begin{array}{l}0 \\
\infty \\
\sigma\end{array}$ & $\stackrel{\check{\gamma}}{\dot{\gamma}}$ & ウं & $\stackrel{\wedge}{\infty}$ & $\begin{array}{l}\text { or } \\
\dot{\infty}\end{array}$ & $\stackrel{\circ}{\stackrel{\dot{\sigma}}{\forall}}$ & $\stackrel{\circ}{\stackrel{i}{\infty}}$ & \\
\hline & & $\begin{array}{l}\text { ભ̆ } \\
\text { ऽ̆ }\end{array}$ & 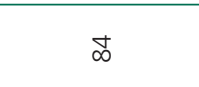 & $\stackrel{\circ}{\wedge}$ & $\begin{array}{l}*^{*} \\
\sigma\end{array}$ & $\stackrel{\infty}{\sim}$ & 1 & 1 & 1 & \\
\hline & 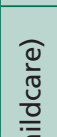 & 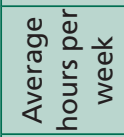 & $\stackrel{\infty}{\sim}$ & $\bar{m}$ & $\stackrel{\mathrm{m}}{ }$ & ㅇ & 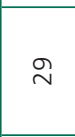 & $\stackrel{\llcorner}{m}$ & 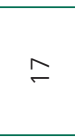 & \\
\hline & 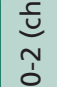 & ஜ̊ & $\stackrel{a}{m}$ & $\stackrel{\sim}{\stackrel{\infty}{\infty}}$ & $\begin{array}{l}\stackrel{\infty}{\infty} \\
\stackrel{\infty}{\sim}\end{array}$ & $\begin{array}{l}\varphi \\
\ddot{q}\end{array}$ & $\stackrel{n}{\stackrel{n}{\circ}}$ & $\begin{array}{l}0 \\
\infty\end{array}$ & $\stackrel{\bullet}{\sim}$ & \\
\hline & 号 & $\begin{array}{l}\text { ळે ু } \\
\text { ळ }\end{array}$ & $\sim$ & $m$ & 6 & $\stackrel{\sim}{\simeq}$ & 1 & 1 & 1 & \\
\hline \multirow{2}{*}{ 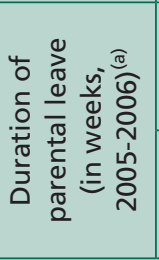 } & \multicolumn{2}{|c|}{ 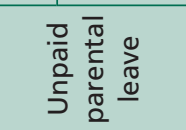 } & $\stackrel{\iota}{\sim}$ & $\stackrel{\infty}{\sim}$ & $\stackrel{\searrow}{\sim}$ & $\stackrel{\searrow}{\sim}$ & กิ & 1 & 1 & \\
\hline & \multicolumn{2}{|c|}{ 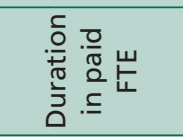 } & 1 & 1 & $\begin{array}{l}\varphi \\
m\end{array}$ & 1 & மீ & $\widehat{\stackrel{N}{N}}$ & $\begin{array}{l}\dot{\varphi} \\
\stackrel{\omega}{\sim}\end{array}$ & \\
\hline \multicolumn{3}{|c|}{$\begin{array}{l}\text { Ḋ̀ } \\
\stackrel{2}{5} \\
0\end{array}$} & $\begin{array}{l}\frac{\sqrt{\pi}}{\pi} \\
\text { ñ }\end{array}$ & 芯 & $\frac{\text { त्र }}{\text { I }}$ & 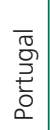 & $\begin{array}{l}\frac{2}{\sqrt{0}} \\
\frac{0}{0} \\
\frac{1}{3} \\
\text { Ty }\end{array}$ & $\begin{array}{l}\frac{\overrightarrow{0}}{\mathrm{C}} \\
\frac{\pi}{0} \\
\frac{0}{0}\end{array}$ & 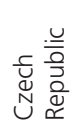 & \\
\hline
\end{tabular}


faster in Spain than in Greece or Italy (Table 4). However, state assistance for reconciling work and family life is still very limited. Parental leave on the birth of a child is unpaid, other financial assistance related to the presence of a child is fairly limited, and preschool provison varies considerably across Spain. Consequently, the increase in the female employment rate has been accompanied by a considerable drop in the fertility rate and a two-fold increase in the proportion of women without children (Table 2). In the absence of any specific support, the increase in female labour force participation observed for a given number of children probably reflects the combination of two processes: improved conditions for managing the work-life balance that have benefited a minority of women, and a greater selection of mothers among women who are in a position to reconcile work with childcare.

Portugal stands out from the other Mediterranean countries for several reasons. From 1992, the female employment rate in Portugal was far higher and continued to grow because low average wages made women's employment more of an economic necessity than elsewhere (OECD, 2004). As a result, female employment is relatively insensitive to the presence of a spouse. However, as in other southern European countries, part-time work is not widely developed and the number of children is the determining variable in the level of labour force participation, whereas the age of the youngest child and the timing of the first birth have little importance. As in Spain, the number of working women with at least two children increased over the period, but their percentage fell. Mothers of young children are better able to reconcile work and family life since childcare provision for children aged under three has improved (Table 4), and tax policy has changed to make women's work more financially advantageous, whatever their family situation (OECD, 2004). At the same time, family sizes are smaller today, although the proportion of women without children has not risen as sharply as in Spain. These two factors appear to explain the increase in the female employment rate.

The three East European countries (Czech Republic, Hungary and Poland) also share a number of characteristics. For instance, the number of children and the age of the youngest child are discriminating factors in female employment. Here, more than elsewhere, women stop working when they have a child under three years old. In Poland, the presence of a child usually leads to short parttime working, while inactivity is more frequent in the two other countries. In all cases, labour force participation is very dependent on the youngest child entering the primary school system, since childcare provision for children under six is scarce.

\section{Conclusion: a risk of polarization}

Our analysis has highlighted persistent differences in the regimes of female labour force participation across Europe. These specificities appear throughout 
the family life cycle and are not restricted to the choices resulting from the presence of a young child. The age of the children is a key factor influencing women's labour force participation and their working hours. The differences between countries are often more visible after early childhood, which is the period targeted by social policies.

We have observed different trends in female employment rates and household structure across Europe. While the increase in the female employment rate is partially due to the reduction in family size or the postponement of family formation, the labour force participation of women with children has nonetheless increased thanks to a more favourable context for reconciling work and family life and to the development of specific forms of support. Another type of behaviour appears to be emerging, however, namely the decision to have a child only if its birth can be reconciled with employment. The growing proportion of working mothers illustrates in this case the increasing polarization associated with this choice. We find indicators reflecting this situation in Germany, Spain, the Netherlands and Portugal, where support for managing the work-life balance is limited. In these countries, the growing proportion of working mothers has been accompanied by a sharp increase in the number of women without children or who have postponed the birth of their first child. Conversely, a lesser reduction in family size is observed in Belgium and in France, where the context is historically more favourable to reconciling work and children, ${ }^{(6)}$ as well as in the United Kingdom where it has considerably improved.

This analysis could be extended to take more explicit account of these parallel trends in employment and fertility decisions. While for the purposes of this article we have reasoned in terms of given characteristics, further analysis would enable us to identify more precisely the extent to which changes in women's employment behaviour are related to a voluntary restriction in family size.

Acknowledgements: I would like to thank the referees and Cédric Afsa-Essafi for their suggestions as well as Laurent Toulemon, France Prioux and Marie-Paule Reydet for their help in finalizing this paper. My thanks also to Ana Franco and Sylvain Jouhette from Eurostat for providing access to data. However, I alone am responsible for the content and for any errors that may remain.

(6) See Thévenon (2009) for a more detailed account of the context in France. 


\section{APPENDIX}

\section{The log-linear model used to model women's labour market situation}

The influence of household composition on women's labour force participation over the period 1992-2005 is estimated using a log-linear model describing the relationships between the different variables of interest. To this end, the labour market situations are modelled under the assumption that the probabilities of each employment situation vary multiplicatively according to women's characteristics.

Here, the included characteristics are survey year, woman's year of birth, her educational level, number of children, age of youngest child, her age at first birth and the presence of a spouse differentiated by employment status.

We will assume, for the sake of simplicity, that only the employment situation $e$ and three other variables (family situation $i$, time $j$, and woman's age $k$ ) are included in the model. We are interested in employment situations conditionally to the other variables $\hat{p}(e \mid i j k)$. These conditional probabilities are assumed to depend upon correlations of the employment variable $e$ with, on the one hand, the other variables $(i, j, k)$ and, on the other, the combinations of these other variables in pairs ( $i j, i k$ and $j k$ ) or threes (ijk). We thus write:

Since we have:

$$
\hat{p}(e \mid i j k)=\frac{\hat{p}_{e i j k}}{\hat{p}_{i j k}}
$$

$$
\hat{p}_{e i j k}=\hat{p}_{i j k} \mu_{0} \mu_{e} \mu_{i e} \mu_{j e} \mu_{k e} \mu_{i j e} \mu_{j k e} \mu_{i k e} \mu_{i j k e}
$$

and if we write, for each variable $i$ entering the model:

$$
\mu_{i}(e)=\mu_{i e}
$$

for each employment situation e, the conditional probability $\hat{p}(e \mid i j k)$ is thus written:

$$
\hat{p}(e \mid i j k)=\mu_{0} \mu(e) \mu_{i}(e) \mu_{j}(e) \mu_{k}(e) \mu_{i j}(e) \mu_{i k}(e) \mu_{j k}(e) \mu_{i j k}(e)
$$

where the incidence of each variable $i$ is measured by the corresponding parameter $\mu_{i}(e)$; the parameter $\mu_{0} \mu(e)$ represents the frequency of the situation $e$ for a mean situation of the other variables $i$ to $k$. In addition to the direct "effects" of the variables $i, j, k$, we include here, via the parameters $\mu_{i j}(e), \mu_{i k}(e)$, 
$\mu_{j k}(e)$ and $\mu_{i j k}(e)$, the first-, second- and third-level interactions between the different variables "explaining" the employment situation, and the employment situation itself. This enables us to capture changes over time in the effects of each characteristic, measured here by the product of the corresponding parameter with that of the survey year and their interaction term. The specific change in the influence of the presence of a child can thus be distinguished from the women's age or cohort effect, and from changes attributable to other characteristics.

The influence of each characteristic of the family situation is represented in the various figures by its marginal effect on the estimated frequencies of the different employment situations, all other things being equal. The effect of the number of children $i$ is this obtained by the following relation:

$$
\hat{p}_{i}(e)=\mu_{0} \mu(e) \mu_{i}(e)
$$

where $\mu_{i}(e)$ measures the way in which the presence of children $i$ modifies the probability $\mu_{0} \mu(e)$ of being in the employment situation $e$. For each family situation $i$, the sum of estimated frequencies for all employment situations thus equals $100 \%$. The same treatment is applied to the other family characteristics.

Likewise, the change over time $j$ of the influence of children can be estimated by taking account of the mean change in employment situations over the period $\left(\mu_{j}(e)\right)$ and of the differences in changes by family situation (measured by the parameters of interaction $\mu_{i j}(e)$ between these two variables). The change over time of the effect of number of children is thus identified by the following relation:

$$
\hat{p}_{i j}(e)=\mu_{0} \mu(e) \mu_{i}(e) \mu_{j}(e) \mu_{i j}(e)
$$

The change specific to the influence of children is thus isolated from the age effects $k$ :

$$
\hat{p}_{i j k}(e)=\mu_{0} \mu(e) \mu_{i}(e) \mu_{j}(e) \mu_{k}(e) \mu_{i j}(e)
$$

In practice, more variables are present, the interactions of the employment situation with three variables are taken into account, and the Equation (4) thus describes a model where the distribution of women by labour market situation varies according to the other variables, taken alone, in pairs or in threes.

The model is estimated here by minimizing the discrimination information between the modelled and observed distributions, making it possible to decompose the information into contributions attributable to the different variables corresponding to the partial correlations (Gokhale and Kullback, 1978; Zighera, 1985; Najar, 1987). The correlation of labour market status with the other characteristics is thus broken down into a sum of partial correlations measured conditionally to the other characteristics. 
Information is decomposed by harmonic centring of parameters, making it possible to measure the contribution of each variable or interaction between variables to the dispersion of the dependent variable (Zighera, 2001; Girardin and Ricordeau, 1999). Decomposition of information is useful to identify the variables with the largest role in explaining differences in labour market situation: the share of information provided by a variable depends on its dispersion and on the differences between the employment distributions that are associated with each value taken by this variable. This decomposition shows, for example, that the weight of the variables characterizing the family situation varies from country to country (Thévenon, 2003 and 2007).

\section{REFERENCES}

Adema W., THÉVEnOn O., 2008, "Les politiques de conciliation du travail et de la vie familiale en France vis-à-vis des autres pays de l'OCDE”. Recherches et Prévisions 93, pp. 51-72.

AHN N., Mira P., 2002, "A note on the changing relationship between fertility and female employment rates in developed countries", Journal of Population Economics, 15, pp. 667-682.

BlanCHET D., PENNEC S., 1993, "A simple model for interpreting cross-tabulations of family size and women's labour force participation”, European Journal of Population, 9, pp. 121-142.

Blanchet D., Pennec S., 1996, "Hausse de l'activité féminine : quels liens avec l'évolution de la fécondité ?", Économie et Statistique, 10(300), pp. 95-104.

Blossfeld H.-P., HAKIM C. (eds.), 1997, Between Equalisation and Marginalisation: Women Working Part-time in Europe, Oxford University Press.

D'Addio-Dervaux A., Mira D'ErCole M., 2005, "Fertility trends and the impact of policies", Social, Employment and Migration Working Papers, OECD, Paris.

ESPING-ANDERSEN G., 1990, The Three Worlds of Welfare Capitalism, Princeton University Press, $260 \mathrm{p}$.

Engelhardt H., Kögel T., PrSKWetz A., 2004, "Fertility and women's employment reconsidered: A macro-level time-series analysis for developed countries, 1960-2000", Population Studies. A Journal of Demography, 58(1), pp. 109-120.

EUROSTAT, 2008, EU Labour Force Survey Database, User Guide, http://circa.europa.eu/irc/dsis/ employment/info/data/eu_lfs/index.htm

GiRARDiN V., RiCORDEAU A., 1999, "Analysis of information into margins: a log-linear parametric approach", Document de travail, 1999/14, Université de Caen.

Gokhale D., KullbaCK S., 1978, The Information in Contingency Tables, Marcel Dekker, New York and Basel.

GORNiCK J., MeYerS M., Ross K., 1997, "Supporting the employment of mothers: policy variation across fourteen welfare states", Journal of European Social Policy, 7(1), pp. 45-70.

KEMPENEERS M., LELIĖVRE E., 1993, "Women's work in the EC: five career profiles", European Journal of Population, 9, pp. 77-92.

KÖGEL T., 2004, "Did the association between fertility and female employment within OECD countries really change its sign?", Journal of Population Economics, 17, pp. 45-65.

LEGENDRE F., ThibaUlt F., 2007, "Les concubins et l'impôt sur le revenu en France". Économie et Statistique, 401, pp. 3-21. 
Meulders D., O'DORCHAi S., 2007, "The position of mothers in a comparative Welfare State perspective", in Del Boca D., Wetzels C. (eds), Social Policies, Labour Markets and Motherhood, Cambridge University Press, pp. 3-27.

NAJAR M., 1987, Modèle log-linéaire et structure de l'emploi, PhD thesis in economics, Université Paris X-Nanterre.

OECD, 2004, Babies and Bosses - Reconciling Work and Family Life (Vol. 3): New Zealand, Portugal, Switzerland, Paris, OECD Publishing

OECD, 2007, Babies and Bosses - Reconciling Work and Family Life: A Synthesis of Findings for OECD Countries, vol.5, Paris, OECD Publishing.

PiketTy T., 2005, "L'impact de l'allocation parentale d'éducation sur l'activité féminine et la fécondité en France : 1982-2002", in LeFĖVRE C., FilHON A. (eds.), Histoires de familles, histoires familiales. Les résultats de l'enquête Famille de 1999, Paris, INED, Cahier 156, pp. 79-109.

RUbery J., SMith M., FAGAN C., 1996, Tendances et perspectives dans l'emploi des femmes dans les années 1990, Report for the European Commission, V/2002/96.

THÉVENON O., 1999, "La durée du travail féminin en Europe : entre flexibilité et conformité. Une comparaison des relations emploi-famille en Allemagne de l'Ouest, Espagne, France, aux PaysBas et Royaume-Uni", Recherches et Prévisions, 56, March, pp. 47-66.

THÉVENON O., 2003, Les relations emploi-famille en Europe. Fondement socio-économique des comportements féminins en Allemagne, France, Espagne, aux Pays-Bas et Royaume-Uni, PhD in economics, Université Paris X-Nanterre.

THÉVENON O., 2006, "Régimes d'État social et convention familiale : une analyse des régulations emploi-famille", Économies et Sociétés, série "socio-économie" du travail, 27(6), pp. 1,137-1,171.

THÉVENON O., 2007, L'activité féminine après l'arrivée d'enfants : disparités et évolutions en Europe à partir des Enquêtes sur les Forces de Travail, INED, Document de travail, 148.

THÉVENON O., 2009, "Does fertility respond to work and family-life reconciliation policies in France?", in Noriyuki Takayama and Martin Werding (eds.), Fertility and Public Policy: How to Reverse the Trend of Declining Birth Rates, Cambridge MA and London UK, MIT-Press, Chapter 10.

VlasblOM J., SCHIPPERS J., 2004, "Increases in female labour force participation in Europe. Similarities and differences", European Journal of Population, 20(4), pp. 375-392.

ZigHeRA J., 2001, "Minimisation of discrimination information as a tool for the analysis of massive surveys - loglinear and logit modelling revisited", Fenics working paper, Université de Paris X-Nanterre.

ZigheRA, J. A., 1985, "Partitioning information in a multidimensional contingency table and centring of log-linear parameters", Applied Stochastic Models and Data Analysis, vol 1, pp. 93-108. 
Olivier THÉVENON • INCREASEd WOMEN's LABOUR ForCE PARTICIPATION IN EUROPE: ProgresS IN THE WORK-LIFE BALANCE OR POLARIZATION OF BEHAVIOURS?

This paper analyses trends in women's labour market situations between 1992 and 2005 using data from the European Labour Force Surveys (EU-LFS). These situations are modelled to capture the effects of the presence of a child or children, the age of the youngest child, the mother's age at first birth and the presence of a spouse on women's employment and working hours, and to see how they change over time. The trends observed in some countries challenge the geographical breakdown proposed by the standard typologies of the 1990s. The rise in female labour force participation rates is partly due to the reduction in family size, but women's employment has also increased for a given household size. In some countries, this rise seems to be associated with a decision to have children only if their arrival can be reconciled with employment. Indicators reflecting this situation are found in Germany, Spain, the Netherlands and Portugal, where support for reconciling work and family life is limited. A lesser reduction in family size is observed in Belgium, France and the United Kingdom, however, where the context for reconciling employment and children is more favourable.

\section{Olivier THÉVENON • L'AUGMENTATION DE L'ACTIVITÉ DES FEMMES EN EUROPE : PROGRÈS DE} LA CONCILIATION OU POLARISATION DES COMPORTEMENTS ?

L'évolution des situations d'activité des femmes de 1992 à 2005 est analysée à partir des Enquêtes européennes sur les forces de travail. Ces situations sont modélisées pour rendre compte des effets propres à la présence d'enfant(s), l'âge du plus jeune et l'âge de la mère à la naissance du premier, ou la présence d'un conjoint sur l'emploi et le temps de travail des femmes, ainsi que leurs évolutions. Certains pays ont connu des évolutions qui remettent en question la cartographie proposée par les typologies standards des années 1990.

La croissance des taux d'activité féminine est partiellement due à la réduction de la taille des familles ; mais l'activité des femmes s'est aussi développée à dimension donnée des ménages. Cette augmentation semble aller de pair, dans certains pays, avec le fait d'avoir des enfants uniquement si leur naissance peut être conciliée avec l'emploi. On trouve des indices reflétant cette situation en Allemagne, en Espagne, aux Pays-Bas et au Portugal où les aides à la conciliation demeurent limitées. Par contre, une réduction moins forte de la taille des familles a été observée en Belgique, en France et au Royaume-Uni où le contexte est plus favorable à la conciliation entre travail et enfants.

\section{Olivier THÉVENON • EL AUMENTO DE LA ACTIVIDAD FEMENINA EN EUROPA: ¿PROGRESO DE} LA CONCILIACIÓN O DOLARIZACIÓN DE LOS COMPORTAMIENTOS ?

Este trabajo analiza la evolución de la actividad femenina a partir de las Encuestas europeas sobre las fuerzas de trabajo. Las diferentes situaciones son modelizadas par tener en cuenta el efecto de la presencia de hijos, la edad del más joven y la edad de la madre al nacimiento del mayor, o la presencia de un cónyuge, sobre el empleo y el tiempo de trabajo de las mujeres, así como sobre su evolución. Ciertos países han conocido cambios que han transformado la cartografía propuesta en los años 1990.

El crecimiento de las tasas de actividad femenina es debido parcialmente a la disminución del tamaño de las familias ; pero la actividad femenina se ha desarrollado también a tamaño constante de la familia. En ciertos países, este aumento parece asociado al hecho de tener hijos únicamente si su llegada puede ser conciliada con el empleo. Hay índices que reflejan esta situación en Alemania, España, Holanda y Portugal, donde las ayudas a la conciliación son todavía limitadas. Al contrario, una reducción menos fuerte del tamaño de la familia se observa en Bélgica, Francia y Reino-Unido, donde el contexto es más favorable a la conciliación entre trabajo y vida familiar.

Translated by Krystyna Horko. 